NBER WORKING PAPER SERIES

\title{
DOES CENTRAL BANK INTERVENTION \\ INCREASE THE VOLATILITY OF \\ FOREIGN EXCHANGE RATES?
}

Kathryn M. Dominguez

Working Paper No. 4532

\section{NATIONAL BUREAU OF ECONOMIC RESEARCH 1050 Massachusetts Avenue \\ Cambridge, MA 02138 \\ November, 1993.}

I am grateful to seminer participants at the NBER intemational lunch-group, the NBER Summer Institute, the Stem School at New York University, the Johnson School at Comell University, the Wharton School at the University of Pennsylvania, MIT, Georgetown University and, especially Susan Collins, Martin Evans, Michael Klein and Jim Stock for helpful comments and suggestions on a previous draft, and to the Olin Fellowship program at the NBER for financial support. This paper is part of NBER's research program in International Finance and Macroeconomics. Any opinions expressed are those of the author and not those of the National Bureau of Economic Research. 
NBER Working Paper \#4532

November 1993

\title{
DOES CENTRAL BANK INTER VENTION \\ INCREASE THE VOLATILITY OF FOREIGN EXCHANGE RATES?
}

\begin{abstract}
Since the abandonment of the Bretton Woods system of fixed exchange rates in the carly 1970s, exchange rates have displayed a surprisingly high degree of time-conditional volatility. This volatility can be explained statistically using autoregressive conditional heteroscedasticity models, but there remains the question of the economic source of this volatility. Central bank intervention policy may provide part of the explanation. Previous work has shown that central banks have relied heavily on intervention policy to influence the level of exchange rates, and that these operations have, at times, been effective. This paper investigates whether central bank interventions have also influenced the variance of exchange rates. The results from daily and weekly GARCH models of the $\$ / \mathrm{DM}$ and $\$ / \mathrm{Yen}$ rates over the period 1985 to 1991 indjcate that publicly known Fed intervention generally decreased volatility over the full period. Further, results indicate that intervention need not be publicly known for it to influence the conditional variance of exchange rate changes. Secret intervention operations by both the Fed and the Bundesbank generally increased exchange rate volatility over the period.
\end{abstract}

Kathryn M. Dominguez Kennedy School of Govemment Harvard University 79 J.F. Kennedy Street Cambridge, MA 02138 and NBER 
"The past has shown us that whenever the finance ministers from the Big Five get together there's a lot of rhetoric and little action. Any time there's talk of intervention and outside forces in the market, it creates volatility and uncertainty. But in the long term it doesn't have any lasting inpact," The Wall Street Joumal, 9/23/85.

\section{Introduction}

Foreign exchange intervention operations are a controversial policy option for central banks. In one view, exemplified by the WSJ quote, intervention policy is not only ineffective in influencing the level of the exchange rate, but also dangerous, because it can increase the volatility of the rate. Others argue that intervention operations can influence the level of the exchange rate, and can also "calm disorderly markets", thereby decreasing volatility. Yet others argue that intervention operations are inconsequential, since they neither affect the level nor the volatility of exchange rates. There are a number of empirical studies that examine whether intervention operations affect the level of exchange rates, ${ }^{1}$ but little has been written on the effects of intervention on the variance of rates. ${ }^{2}$ This paper examines the effect of intervention on foreign exchange rate volatility over the period 1985 through 1991.

1 Jurgenson (1983), Loopesko (1984), Obstfeld (1990), Dominguez (1990a,b, 1992), Dominguez and Frankel (1993a,b,c) and see the references in Edison (1993).

2 A notable exception is Baillie and Humpage (1992). Lastrapes (1989) examines the effects of U.S. monetary policy on the volatility of exchange rates. 
During the period in which countries adhered to the Bretton Woods exchange rate system, intervention operations were required whenever rates exceeded their parity bands. After the breakdown of the system in 1973, intervention policy was left to the discretion of individual countries. It was not until 1977 that the IMF Fxecutive Board provided its member countries three guiding principles for intervention policy: (1) countries should not manipulate exchange rates in order to prevent balance of payments adjustment or to gain unfair competitive advantage over others; (2) countries should intervene to counter disorderly market conditions; and (3) countries should take into account the exchange rate interests of others. ${ }^{3}$ These principles implicitly assume that intervention policy can effectively influence exchange rates, and explicitly state that countries should use intervention policy to decrease foreign exchange rate volatility.

After actively engaging in foreign exchange intervention in the $1970 \mathrm{~s}$, the U.S. abandoned intervention policy altogether during the period 1981 through 1984. In early 1985, after the dollar had appreciated by over $40 \%$ against the mark, and the U.S. trade deficit was nearing $\$ 100$ billion, the U.S. joined with the German Bundesbank and the Bank of Japan to intervene against the dollar. In the autumn of 1985 the U.S. and the rest of the G-5 engaged in an unprecedented number of large and coordinated intervention operations

3 IMF executive Board Decision no. 5392-(77/63), adopted April 1977. 
as part of the Plaza Agreement. The G-5 continued to intervene episodically throughout the rest of the $1980 \mathrm{~s}$.

The scale of central bank intervention operations has been large in the post-1985 period relative to that in the early 1980 s, but small relative to the overall size of the foreign exchange market. The New York Fed reports that the average daily volume of foreign exchange trading was $\$ 192$ billion (eliminating double-counting) in the United States in April 1992. By comparison, the average coordinated intervention operation during the late 1980 s involved $\$ 350$ million. ${ }^{4}$ Figures 1 and 2 present bar graphs of U.S. and Gemnan intervention operations in the $1980 s^{5}$ The Bundesbank has maintained the most consistent presence of the G-5 countries in the foreign exchange markets. The Bundesbank intervened steadily during the period before 1985 when the Fed was absent from the market. Germany was reported to have been the major initial force in starting the dollar on its decline in early 1985 through both its own intervention operations and its pressure on the U.S. and Japan to join in coordinated operations.

4 The average coordinated sale of dollars by the Fed and the Bundesbank over the period 1985 through 1988 involved $\$ 350$ million, and the average coordinated purchase of dollars by the two central banks involved $\$ 368$ million.

5 The Bundesbank intervention data used in this paper end in December 1988 and the Fed data end in December 1991. 


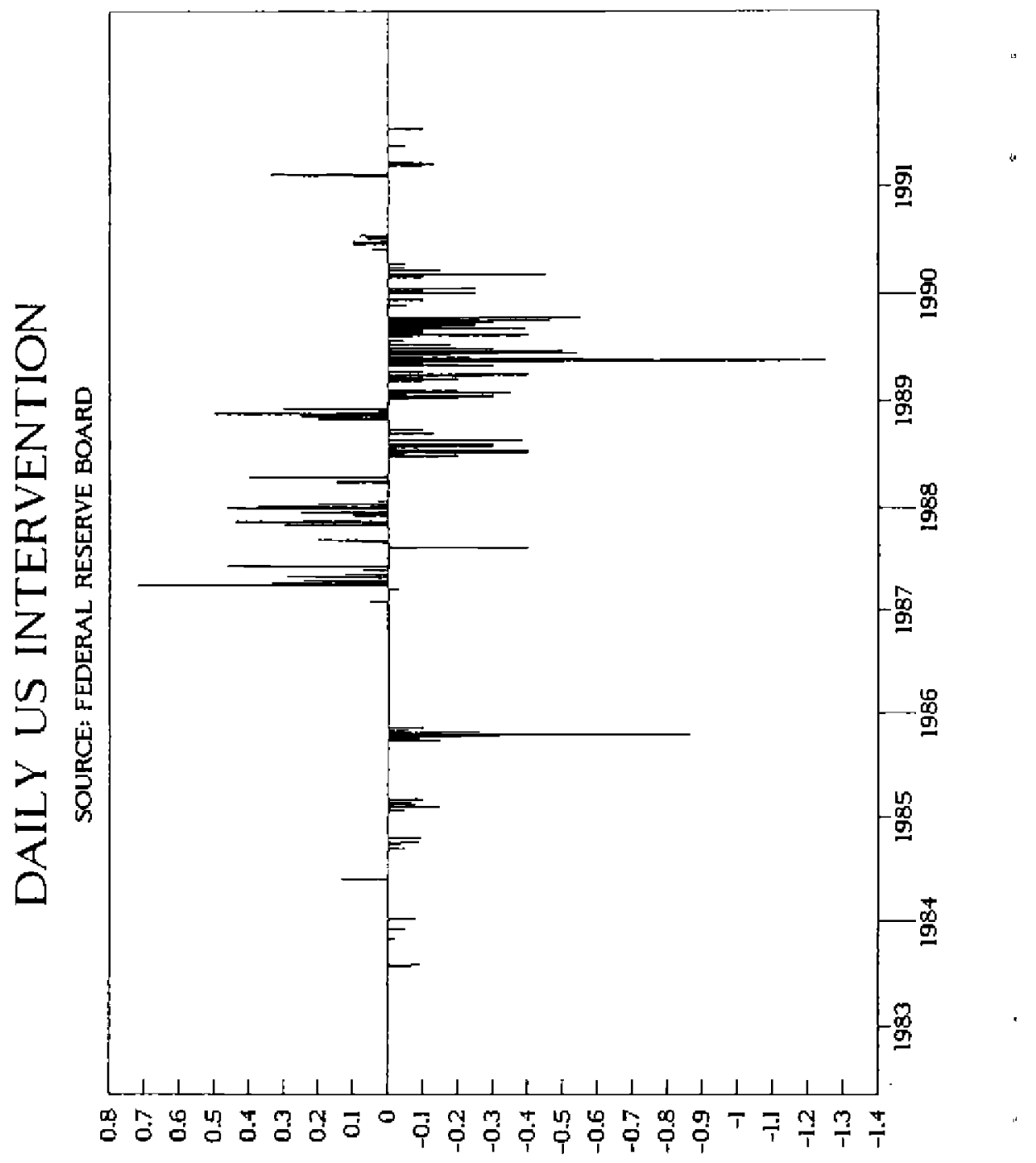

SHV7700 to SNOI77I 


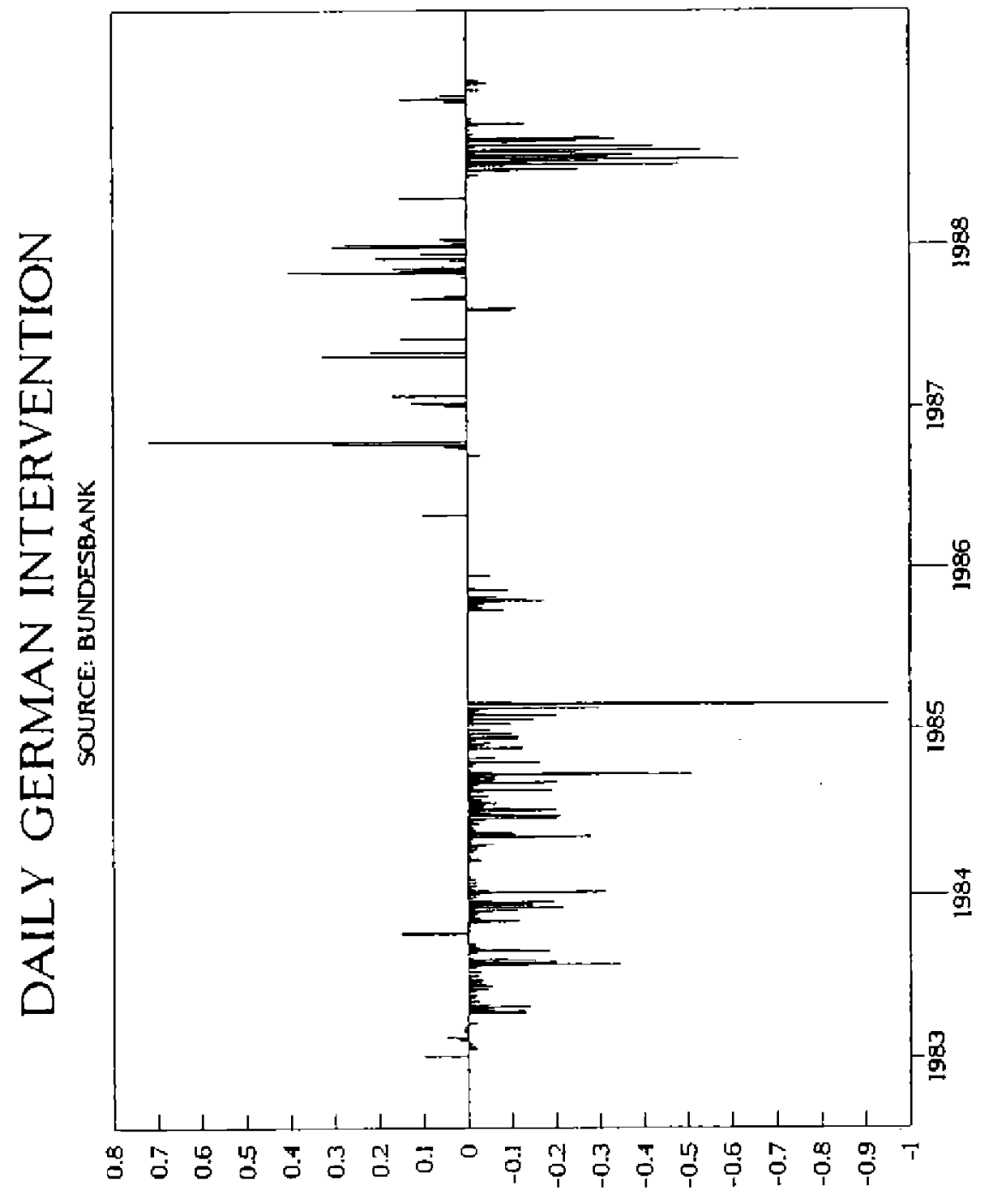

S\&V7าด I0 SNO17าI 
Did the G-5 intervention operations, over the period 1985 through 1991 , influence the volatility of the $\$ / D M$ or the $\$ /$ Yen exchange rates? Section $I I$ begins with a discussion of how central bank intervention policy can influence exchange rate first moments. Section III presents daily and weekly models of exchange rate changes that allow intervention operations to influence both the conditional mean and variance. Estimates of the models are presented in section IV. Section V presents conclusions. Overall, the econometric results indicate that official exchange rate policy often significantly influenced exchange rate volatility.

\section{Can Central Bank Intervention Influence Exchange Rates?}

Foreign exchange market intervention is, most broadly defined, any transaction or announcement by an official agent of a govemment that is intended to influence the value of an exchange rate. In most countries, intervention operations are implemented by the monetary authority, although the decision to intervene can often also be made by authorities in the finance ministry, or treasury department, depending on the country. In practice, central banks define intervention more narrowly as any official sale or purchase of foreign assets against domestic assets in the foreign exchange market.

Although each central bank has its own particular set of practices, intervention operations geverally take place in the broker's market. During major intervention episodes, the Fed often chooses to deal directly with the 
foreign exchange desk of several large commercial banks simultaneously to achieve maximum visibility. As with any other foreign exchange transaction, trades are officially anonymous. However, most central banks have developed relationships with traders which allow them to inform the market of their presence within minutes of the original transaction.

Data on daily official central bank purchases and sales in the foreign exchange market have rarely been made available to researchers outside the central banks, ${ }^{7}$ let alone market participants. Although intervention data have not been published on a daily basis by the central banks, ${ }^{8}$ daily intervention operations are frequently reported in newspapers and over the wire services. So, although current official data are unavailable, there exist numerous unofficial sources of the data. The Appendix to Dominguez and Frankel (1993c) provides a listing of all the news of intervention activity (as well as more general exchange rate policy announcements) by central banks reported in the Wall Street Journal, the London Financial Times and the New York Times over the period 1982 through 1990. Non-reported interventions are not

6 Dominguez and Frankel (1993c) provide a detailed description of this process.

1 Exceptions include Neumann (1984), Dominguez (1990a, b, 1992) and Dominguez and Frankel (1993a,b,c) who were given access to Bundesbank intervention data. There were even fewer exceptions in the case of Federal Reserve Data prior to 1991.

8 The daily U.S. data is now available with a one year lag. 
differentiated in central banks' official data, but one can roughly infer which operations were secret by comparing the official data with published reports of intervention activity in the financial press. Although traders may sometimes know that central banks are intervening without such knowledge appearing in the financial press, this relatively conservative accounting for reported intervention reveals that the bulk of recent intervention is not secret. In the empirical tests described in the next section I distinguish "secret" and "reported" interventions to examine whether the distinction matters in the volatility regressions.

Regardless of whether interventions are made public, intervention operations may influence the domestic monetary base. Nonsterilized intervention operations involve a change in the domestic monetary base; they are analogous to open-market operations except that foreign, rather than domestic, assets are bought or sold. Sterilized operations involve an offsetting domestic asset transaction that restores the original size of the monetary base. The Federal Reserve Bank of New York is thought to fully and automatically sterilize its intervention operations on a daily basis. In practice, the foreign exchange trading room immediately reports its dollar sales to the open market trading room, which then sells enough bonds to leave the daily U.S. money supply unaffected. The Bundesbank also claims to sterilize their foreign 
exchange intervention operations routinely as a technical matter. ${ }^{9}$ Nevertheless, the general perception is that both the Fed and the Bundesbank have at times allowed intervention operations to influence monetary aggregates. Although the degree of monetary accommodation is limited to the extent that they both target their money supply growth.

The standard monetary approach to exchange rate determination indicates that nonsterilized intervention will affect the level of the exchange rate in proportion to the change in the relative supplies of domestic and foreign money, just as any other form of monetary policy does. The effects of sterilized intervention are less direct and more controversial. In portfoliobalance models of exchange rate determination investors diversify their holdings among domestic and foreign assets based both on expected returns and on the variance in returns. According to the theory, as long as foreign and domestic assets are considered outside assets and are imperfect substitutes for each other in investor's portfolios, an intervention that changes the relative outstanding supply of domestic assets will require a change in expected relative returns. ${ }^{10}$ This is likely to result in a change in the exchange rate.

9 See Neumann and von Hagen (1991) for a detailed discussion of German sterilization policy.

10 Branson and Henderson (1985) provide a survey and analysis of portfolio balance models. 
The second channel through which sterilized intervention can affect the level of exchange rates is known as the signalling channel." Intervention operations affect exchange rates through the signalling channel when they are used by central banks as a means of conveying (or signalling), to the market, inside information - information known to central banks but not the market - about future fundamentals. If market participants believe the central bank intervention signals, then even though today's fundamentals do not change when interventions occur, expectations of future fundamentals will change. When the market revises its expectations of future fundamentals, it also revises its expectations of the future spot exchange rate, which brings about a change in the current rate. The magnitude of the signalling effect of a sterilized intervention operation may exceed that of a nonsterilized operation, depending on the magnitude of the future change in monetary policy that the signal conveys.

Is there empirical evidence that intervention operations affect the level of exchange rates? In 1982 the G-7 economic summit at Versailles commissioned a comprehensive study of intervention policy in order to answer this question. The G-7 working group report, completed in 1983, draws no firm conclusions, but suggests that the effects of sterilized interventions on the exchange rate were (at most) small and transitory over the period 1973-1981

1 One of the first descriptions of the signalling channel can be found in Mussa (1981). 
(Jurgenson 1983, Henderson and Sampson 1983). Studies of intervention policy in the 1980 s suggest that more recent operations may have been more effective. $^{12}$ In particular, these studies find that intervention had a statistically significant effect on exchange rates over the period 1985-1988 through both the portfolio balance and signalling channels, but that only the signalling channel effect was economically significant. Moreover, the evidence suggests that coordinated intervention operations were more effective than unilateral operations. ${ }^{13}$

\section{A Model of Daily and Weekly Exchange Rate Behavior}

It is standard to model exchange rates as forward looking processes that are expectationally efficient with respect to public information. The current spot rate can be represented as

12 For example, Dominguez (1990a,b), Black (1992), Catte, Galli and Rebeccheni (1992), Ghosh (1992) and Dominguez and Frankel (1993a,b,c). However, Humpage (1989) finds little evidence of a statistical relationship between intervention and exchange rates over this period.

${ }^{13}$ Loopesko (1984) also finds this to be the case in the late 1970 s. 


$$
s_{t}=(1-\delta) \sum_{k=0}^{\infty} \delta^{k} E_{t}\left(z_{t+k} \mid Q_{l}\right)
$$

where $s_{1}$ is the current spot exchange rate (domestic currency per unit of foreign currency) in $\log$ form, $\delta$ is the discount factor, ${ }^{14} z_{4}$ is a vector of exogenous driving variables, and $\Omega_{t}$ is the public information set at time $t$. If intervention operations, denoted $I_{1}$, provide relevant information to the market, then they will enlarge the market's information set $\left(\Omega_{1}<\Omega_{1}+I_{2}\right)$ and influence the spot exchange rate. For example, if a central bank intervention in support of the domestic currency signals future contractionary domestic monetary policy, the domestic currency will appreciate relative to the foreign currency:

$$
s_{t}=(1-\delta) \sum_{k=0}^{\infty} \delta^{k} E_{i}\left(z_{1+k} \mid \Omega_{t}\right)>(1-\delta) \sum_{k=0}^{\infty} \delta^{k} E_{t}\left(z_{t+k} \mid \Omega_{t}+I_{t}\right)
$$

where, in this example, $I_{t}$ represents an official purchase of domestic assets.

In practice, exchange rate determination models that include variables other than the current spot rate have had limited success in explaining shortterm movements of exchange rates. ${ }^{15}$ Daily and weekly changes in the spot

I4 In the monetary approach, $\delta=\beta / 1+\beta$, where $\beta$ is the interest semielasticity of money demand.

15 Meese and Rogoff (1983) and Levich (1985) provide surveys of empirical exchange rate behavior results. 
exchange rate appear to be largely driven by unanticipated news. At the same time, studies by Westerfield (1977) and Hsieh (1988) find evidence of unconditional leptokurtosis in exchange rate changes. This suggests that there exists temporal clustering in the variance of exchange rate changes: large changes are followed by large changes, and small changes by small changes. Hsieh (1989) and Diebold and Nerlove (1989) document that there is strong evidence of autoregressive conditional heteroscedasticity (ARCH) in the one step ahead prediction errors for daily and weekly dollar exchange rates. ${ }^{16}$ They conclude that the disturbances in the exchange rate process are uncorrelated but not stochastically independent. This suggests that even if short-term exchange rate changes are not predictable, the variance of exchange rate changes may be.

If we denote the one period change in the exchange rate as $\Delta s$, then an empirical model of exchange rate changes can be represented as

$$
\Delta s_{t}=z_{t} \beta+\varepsilon_{t}
$$

where $\mathrm{z}_{\mathrm{1}}$ includes news and intervention variables, and $\varepsilon_{1}$ is the disturbance term. The conditional mean of the disturbance in (3) is $E\left[\varepsilon_{t} \mid \Omega_{t-1}\right]=0$, (where $\Omega_{t-1}$ now includes $\left.I_{t-1}\right)$ and the $\operatorname{GARCH}(1,1)$ conditional variance is $\operatorname{var}\left[\varepsilon_{\mathrm{t}} \mid \mathbf{Q}_{\mathrm{t}-1}\right]$

16 Engle (1982) is the first application of ARCH to price data. Bollerslev's (1986) generalized autoregressive conditional heteroscedasticity model (GARCH) extends the ARCH class of models to allow the conditional variance of exchange rate prectiction errors to depend on lagged conditional variances as well as past sample variances. 
$=\operatorname{var}\left[\Delta \mathrm{s}_{1} \mid \Omega_{\mathrm{t}-1}\right]=v_{\mathrm{t}}=\alpha_{0}+\alpha_{1} v_{\mathrm{t}-1}+\alpha_{2} \varepsilon_{\mathrm{t}-1 *}^{2}{ }^{17}$ If central bank intervention does not signal future fundamentals, but instead is based on current movements of the exchange rate, then $E\left[\varepsilon_{1} \mid n_{t-1}\right] \neq 0 ; I_{t-5}$ will not be an appropriate righthand-side variable in (3). Dominguez and Frankel (1993c) find that the intervention operations that took place in the mid-1980s cannot be well explained on the basis of past exchange rate movements. But this hypothesis will be tested in the next section of the paper.

A GARCH specification of the conditional variance of the disturbances in (3) allows for adaptive learning by market participants; the variability of today's exchange rate depends on past variability. Diebold and Nerlove (1989) suggest that the nature of incoming information in asset markets may explain this nonlinear serial dependence. "When signals are relatively clear (i.e. easily and unambiguously interpretable) then, conditional upon those signals, exchange rate volatility is likely to be low. When there is disagreement about the meaning of incoming information, or when clearly relevant and significant information is scarce, we would expect greater market volatility" (Diebold and Nerlove 1989,19).

A hypothesis that can be tested using the GARCH model is that secret interventions are inherently ambiguous signals and they are consequently more

17 The unconditional mean of the disturbance term is $E\left[\varepsilon_{l}\right]=0$ and the unconditional variance is $\operatorname{var}\left[\varepsilon_{l}\right]=\operatorname{var}\left[\Delta s_{1}\right]=\alpha_{0} /\left(1-\alpha_{1}-\alpha_{2}\right)$. 
likely to increase uncertainty in the market. Secret interventions are likely to be ambiguous signals of both intervention policy and future fundamentals. Reported interventions presumably provide clearer signals of intervention policy. Ghosh (1992) and Kaminsky and Lewis (1993) test whether intervention belps forecast future monetary policy. Both studies find evidence that knowiedge of intervention policy does improve predictions of future monetary policy. ${ }^{18}$

Hsieh (1988) finds evidence that both day-of-week and holiday dummy variables should be included as explanatory variables in daily exchange rate GARCH models. Further, Hsieb (1989) shows that, in practice, it is difficult to identify the correct number of lags to be included in the conditional variance equation of a GARCH model. Bollerslev (1986), Hsieh (1989), and Baillie and Bollerslev (1989) find evidence that the GARCH(1,1) using a conditional Student $t$ distribution, rather than the normal distribution, is the most appropriate model for daily exchange rate data. ${ }^{19}$ I follow this

18 Kaminsky and Lewis (1993) strongly reject the hypothesis that intervention provides no information about future monetary policy. But they find that subsequent monetary policy changes are frequently in the opposite direction to what was signalled.

19 Bollerslev (1986) estimates a $\operatorname{GARCH}(1,1)$ for daily exchange rate observations for the period 1980 to 1985 using a conditional Student $t$ distribution. Baillie and Bollerslev (1989) estimate a GARCH $(1,1)$ for daily exchange rate observations for the period 1980 to 1985 using the Student $t$ and the power exponential distributions. Hsieh (1989) estimates a GARCH $(1,1)$ for daily exchange rate observations for the period 1974 to 1983 using the normal, 
convention and include day-of-week and holiday dummy variables in the daily model specification. Secret and reported intervention variables are included separately in both the conditional mean and variance equations. In the conditional mean equation, the intervention variables are included, so that positive values denote purchases of dollars, and negative values denote official dollar sales. In the conditional variance equation, intervention variables are included in absolute value form. I also include the spread between the German or Japanese interbank interest rate and the U.S Federal Funds rate in both the conditional mean and variance equations to control for relative contemporaneous monetary policies in the three countries. ${ }^{20}$ The GARCH( $(1,1)$ models of the $\$ / D M$ and $\$ /$ Yen exchange rates that I estimate have the following general specification:

Student $t$, GED, normal-Poisson, and normal-lognormal distributions. All three studies found that daily exchange rate data was best modelled with the Student $t$ distribution.

20 In the daily model the German and Japanese interest rates are the interbank money spot offer rate (Reuters), and the U.S. interest rate is the effective Federal Funds rate (Federal Reserve Bank of New York). The source for these series is DRI. In the weekly model, the German data is the Repo rate (Monthly Report of the Bundesbank), the Japanese data is the Call Money rate (Fed H.13 release) and the US data is the weekly average Federal Funds rate (Federal Reserve Board). 


$$
\begin{aligned}
\Delta s_{t}=\beta_{0}+\sum_{i=1}^{4} \beta_{t} D_{t t}+\beta_{5} H_{t}+\beta_{6} I_{t-1}^{U S}+\beta_{7} I_{t}^{B B}+\beta_{8} I_{t-1}^{S}+ \\
\beta_{9} I_{t}^{B O I}+\beta_{10} N_{t-1}+\beta_{11} \Delta i_{t-1}+\beta_{12} \sqrt{v_{t}}+\varepsilon_{t}
\end{aligned}
$$

$$
\begin{gathered}
\varepsilon_{t} \mid \Omega_{t-1}-N\left(0, v_{p} n\right) \\
v_{t}=\alpha_{0}+\alpha_{1} v_{t-1}+\alpha_{2} \varepsilon_{t-1}^{2}+\phi_{1} H_{t}+\Psi_{1}\left|I_{t-1}^{U S}\right|+\Psi_{2}\left|I_{s}^{B B}\right| \\
+\Psi_{3}\left|I_{t-1}^{s}\right|+\Psi_{4}\left|I_{t}^{B O}\right|+\Psi_{s}\left|N_{t-1}\right|+\Psi_{6} \Delta i_{t-1}
\end{gathered}
$$

where $\Delta s_{\mathrm{t}}$ is the log change in the $\$ / \mathrm{DM}$ or $\$ /$ Yen spot exchange rate between period $t$ and $t-1, D_{i 1}$ are day of the week dummy variables (i.e., $D_{11}=1$ on Mondays), $\mathrm{H}_{\mathrm{t}}$ is a holiday dummy variable that is equal to one on the day following the market being closed for any reason other than a weekend, $I_{-1}^{U S}$ is a variable capturing reported Fed intervention operations known at time $t$, $I_{\mathrm{f}}^{\mathrm{BP}}$ is a variable capturing reported Bundesbank intervention operations known at time $t,{ }^{21} I_{t-1}^{s}$ is a variable capturing "secret" Fed and Bundesbank

21 Bundesbank intervention operations need not be lagged one period (as is the case for Fed interventions) because the exchange rate data are New York market open data and Germany is six hours ahead of New York. Market participants cannot know (with certainty) the Fed's Tuesday interventions on Tuesday morning (at the market opening), but the Bundesbank's operations may be known because they will have already taken place. 
intervention operations at time $t,{ }^{22} I_{1}^{\mathrm{BOS}}$ is a $(-1,0,1)$ dummy variable capturing reported Bank of Japan intervention operations known at time $t^{23} N_{1-1}$ is a $(-1,0,1)$ dummy variable capturing exchange rate policy news (excluding intervention), ${ }^{24} \Delta \mathbf{i}_{\mathrm{l} . \mathrm{l}}$ is the spread between German or Japanese and U.S. overnight interest rates, || is the absolute value operator and $\varepsilon_{1}$ is the disturbance term. The conditional distribution of the disturbance term is standardized $t$ with variance $v_{\mathrm{l}}$ and degrees of freedom $n$. The $t$ distribution approaches a normal distribution as the parameter $n$ approaches infinity. The last explanatory variable in equation (4) allows for the possibility that changes in the conditional variance influence the conditional mean.

The GARCH models are estimated using the maximum likelihood procedure described in Berndt, Hall, Hall and Hausman (1974). The loglikelihood function of the data is given by:

${ }^{2}$ The intervention variables are in billions of dollars $(\$ 1$ billion $=1)$.

2 Official BOr daily intervention data is not available to the public. The BOJ data used in the regressions was collected from the financial press. Negative one denotes days in which the BOJ was reported to have intervened against the dollar, positive one denotes days in which the BOJ was reported to have intervened in support of the dollar, and zero denotes days in which the BOJ was not reported to have intervened in the foreign exchange market.

${ }^{24}$ Negative one denotes days in which an official G-3 (the U.S., Germany and Japan) statement was made against the dollar, positive one denotes days in which an official G-3 statement was made in support of the dollar, and zero denotes days in which no such announcements were made. The content of these announcements is in the Appendix of Dominguez and Frankel (1993c). 


$$
\begin{aligned}
L_{T}(\theta)= & T\left[\log \Gamma\left(\frac{n+1}{2}\right)-\log \Gamma\left(\frac{n}{2}\right)-\frac{1}{2} \log (n-2)\right] \\
& -\frac{1}{2} \sum_{t=1}^{r}\left[\log v_{t}+(n+1) \log \left(1+\varepsilon_{t}^{2} v_{s}^{-1}(n-2)^{-1}\right)\right]
\end{aligned}
$$

where $\Gamma$ denotes the gamma function and $\theta=(\beta, \alpha, \phi, \psi)$.

The Fed and Bundesbank intervention data series used in the empirical tests measure consolidated daily official foreign exchange transactions in billions of dollars at current market values. The Fed data exclude so-called "passive" intervention operations. Passive interventions are Fed purchases and sales of foreign currency with customers who would otherwise have dealt with market agents. ${ }^{25}$ The Bundesbank data excludes non-discretionary interventions required by EMS rules.

The exchange rate data used in the empirical tests are New York market opening (9am EST) spot \$/DM and \$/Yen prices (bid side) compiled by the Federal Reserve Bank of New York. ${ }^{26}$ Table 1 presents various descriptive statistics for the $\$ / D M$ and $\$ / Y e n$ rates over various subsamples in the time period 1985 to 1991 . These statistics confirm that daily exchange rates are strongly heteroscedastic martingale processes and weekly data are

25 Adams and Henderson (1983) provide detailed discussion and definition of customer transactions.

${ }^{26}$ I am grateful to Carol Osler for providing the spot data. 
weakly heteroscedastic. These findings are consistent with the previous literature.

The subsamples used in the empirical tests throughout the paper were chosen on the basis of pre-announced intervention regime changes and data availability. The first subsample includes the period January 1985 through mid-February 1987. During this period, which includes the Plaza Agreement, ${ }^{27}$ the dollar fell by over $50 \%$ against the mark. In the early part of subsample (1) the G-5 central banks explicitly stated that their goal was to depreciate the dollar. But by 1986 both the Bundesbank and the Bank of Japan indicated - both verbally and through their intervention operations - that the dollar had fallen far enough, while the U.S. continued to "talk" the dollar down, but abstained from further interventions against the dollar. Nevertheless, throughout the period the central banks' stated intention was to affect the level rather than the yariance of exchange rates. Subsample (2) is the full sample over which the both the Bundesbank and Fed data are available, January 1985 through December 1988. Subsample (3) covers the Post-Louvre Accord period, February 1987 through December 1991. The G-7 (excepting Italy) produced the Louvre Accord in late February 1987 which stated that

27 The Plaza Agreement communique stated that "in view of the present and prospective changes in fundamentals, some orderly appreciation of the main non-dollar currencies against the dollar is desirable. They [the Ministers and Governors] stand ready to cooperate more closely to encourage this when to do so would be helpful" (G5 Announcement, September 22, 1985). 
nominal exchange rates were "broadly consistent with underlying economic fundamentals" and should be stabilized at their current levels (G-6 Communique, Februaty 22,1987$).{ }^{2}$ Subsample (4) is the full sample over which the Fed data are available, January 1985 through December 1991.

The statistics in Table 1 indicate that skewness and kurtosis are generally significant in the raw daily and weekly $\$ / D M$ and $\$ /$ Yen data. Percentage changes in both the \$/DM and \$/Yen spot data consistently exhibit a high degree of kurtosis over all subsamples for all but the weekly percentage change in the \$/DM rate. The Box-Pierce Q-statistic tests for high-order serial correlation generally indicate that the squared percentage change spot data exhibit substantially more autocorrelation than the unsquared data $\$$ This is indicative of strong conditional heteroscedasticity. The first four sample autocorrelation and partial autocorrelation coefficients for the raw \$/DM and $\$ /$ Yen exchange rates over the full sample period are presented in the lower portion of Table 1; they indicate homogeneous nonstationarity. The first lag of the sample partial autocorrelation is approximately one, and subsequent lags are insignificantly different from zero. Standard Dickey-Fuller tests for unit

28 Two recent papers have examined whether dollar exchange rates in the post-Louvre Accord period behaved as if they were in a target zone (Klein and Lewis (1991), Baillie and Humpage (1992)).

29 Under the null hypothesis of iid, the Q-statistic is asymptotically a chisquared distribution with $\mathrm{x}$ degrees of freedom. The null hypothesis requires that $x$ increase with the sample size but at a slower rate (Hsieh, 1989, 307). 
roots fail to reject the hypothesis of a unit root in the daily and weekly spot data over all subsamples, while the Hasza and Fuller (1979) test for two unit roots is rejected.

\section{Estimation Results}

Tables $2 \mathrm{a}$ through $6 \mathrm{~b}$ present estimates from the $\operatorname{GARCH}(1,1)$ exchange rate model described by equations (4)-(6) over the four subperiods using daily and weekly $\$ / D M$ and $\$ /$ Yen data. Table numbers with the suffix $a$ present the daily model estimates, and table numbers with the suffix $b$ present the weekly model estimates. Tables $2 a$ and $2 b$ present estimates of the conditional mean equation (4) over all four subperiods. Tables $3 a$ through $6 b$ present estimates from three alternative specifications of the conditional variance equation. Each table covers one of the four subperiods. Table 7 presents results of Granger-Causality tests of the GARCH conditional variance and the independent variables from the model.

Although the focus of this paper is the influence of exchange rate policy on the volatility of exchange rates, it is interesting to examine the results from the GARCH conditional mean equation. The results from the daily model, presented in Table 2a, indicate that the day-of-the-week dummy variables are statistically significant in samples (2) and (4) for both the \$/DM and $\$ /$ Yen exchange rates. The holiday dummy variable is never statistically significant. The coefficients on the reported intervention variables are 
generally significant. But the coefficient sign on the intervention variables is typically positive, suggesting that on the day following a dollar supporting intervention operation, the dollar fell in value. Reported Fed intervention in the Plaza period, however, is significant and negative for the \$/DM rate. The coefficient on the News variable is also negative and generally highly significant over all the subperiods. The interest rate spread variable is never significant. The GARCH-in-mean term is always positive and often significant, suggesting that higher volatility generally led to dollar depreciation over this period. Estimates using the weekly data, presented in Table $2 b$, provide similar results in terms of the signs on the coefficients. However, particularly in the $\$ /$ Yen equations, few of the coefficients in the weekly regressions are statistically significant.

Tables 3a through $6 \mathrm{~b}$ include three specifications of the conditional variance equation. The first is a basic $\operatorname{GARCH}(1,1)$ model excluding the additional exchange rate policy variables, the second is the specification described in equation (6), and the third is a modified version of equation (6) where the intervention variables are included as $(0,1)$ dummy variables rather than as magnitudes. It may be that what influences volatility is the presence of central banks in the market, regardless of the magnitude of the actual intervention operation. The GARCH model specification that includes onty dummy variables allows a test of this hypothesis. 
A number of regression diagnostics are presented at the bottom of the tables: (ln L) denotes the value of the log-likelihood function, $\rho$ denotes the number of iterations that were needed to reach model convergence, $Q_{2}(x)$ and $\mathrm{Q}_{\mathrm{z}}(\mathrm{x})$ denote the Box-Pierce $\mathrm{Q}$-statistic (with $\mathrm{x}$ lags) for the standardized residuals $\left(\mathrm{z}=\varepsilon_{\mathrm{l}}\left(v_{v^{-1 / 4}}\right)\right.$ and the squared standardized residuals, respectively. According to the distributional assumptions in equation (5), the standardized residuals should be normally distributed if the GARCH model accounts fully for the leptokurtic unconditional distribution. The standardized residuals from all the regression specifications over all subsamples have mean values that are insignificantly different from zero and variance values that are approximately equal to one. Further, the absolute size of both the Q-statistics and the coefficients of skewness and kurtosis in the standardized residuals is generally smaller than that of the unadjusted residuals, presented in Table 1, providing support for the GARCH models.

The estimates in Tables $3 a$ and $3 b$ are for the pre-Louvre Accord subsample, January 1985 through mid-February 1987. The first three explanatory variables included in the first and fourth columns of Table 3a are generally highly significant, indicating that the GARCH parameters $\left(\alpha_{0}, \alpha_{1}, \alpha_{2}\right)$ have explanatory power in the daily model. The magnitude of the coefficient on the lagged conditional variance, $\alpha_{1}$, is about .8 and highly significant, indicating that the variance effect is highly persistent. In both the \$/DM and 
$\$ /$ Yen equations reported Fed and Bundesbank intervention are significant and negative, indicating that intervention reduced volatility in this subperiod. In the $\$ /$ Yen equations the interest rate spread variable is also significant and negative. The distribution parameter $n$ is highly significant and relatively small, suggesting that the disturbances are not normally distributed.

The estimates of the distribution parameter $\boldsymbol{n}$ in the GARCH models using weekly $\$ / D M$ and $\$ /$ Yen data were generally extremely large (greater than 500) over all the subperiods, indicating that the disturbances from the weekly model are approximately normally distributed. Therefore the weekly conditional variance equations were estimated assuming normally distributed disturbances. The log-likelihood function for the weekly $\operatorname{GARCH}(1,1)$ models is given by:

$$
L_{J}(\theta)=\frac{1}{T} \sum_{t=1}^{T}-\frac{1}{2}\left(\log v_{t}+\frac{\varepsilon_{t}^{2}}{v_{t}}\right)
$$

where $\theta=(\beta, \alpha, \phi, \psi)$. The standard GARCH model using the normal distribution contains a potentially important restriction in the conditional variance function. Intuitively, this functional form forces larger innovations in $\varepsilon_{\mathrm{t}}$ to increase volatility at a rate proportional to the square of the size of the innovation. Engle and $\mathrm{Ng}$ (1992) provide a set of diagnostics that test the restrictions in GARCH models with normally distributed disturbances. The row labeled E\&N at the bottom of each of the tables presenting weekly results 
indicates whether any coefficient estimate from the Engle and $\mathrm{Ng}$ (1992) diagnostic regression indicates that the GARCH restrictions are violated.

In the weekly models over the pre-Louvre subperiod, the only GARCH parameter that is significant is the lagged conditional variance. In the \$/DM equations the variance effect is similar in size to that in the daily model. The variance effect is much smaller in the weekly $\$ /$ Yen equations. Reported Bundesbank intervention magnitudes are significant for both the \$/DM rate and the $\$ /$ Yen rate, but the sign on the coefficient is not the same. In the $\$ / D M$ case Bundesbank intervention increased volatility and in the $\$ /$ Yen case Bundesbank intervention reduced volatility. Secret intervention is significant for both currencies and always positive. The interest rate spread variable is also highly significant and positive for the \$/DM rate.

Tables $4 a$ and $4 b$ present estimates for the full period over which the Bundesbank data is available, 1985 through 1988. The three GARCH parameters are again highly statistically siguificant in the daily equations and the daily variance effect is highly persistent. The holiday dummy variable is now positive and significant. In the weekly tests, the size of the coefficient on the conditional variance term remains high for the \$/DM rate, and is about .3 for the $\$ /$ Yen rate. In the daily GARCH estimates both secret intervention and the interest rate spread variable are significant and positive for the \$/DM rate. BOJ intervention is significant and positive, and Bundesbank intervention is significant and negative for the $\$ /$ Yen rate. In the weekly GARCH estimates, 
presented in table $4 b$, the coefficient on publicly known Fed intervention is negative and generally statistically significant for both currencies. This suggests that, overall, Fed intervention that was known to market participants decreased weekly volatility over the period 1985 through 1988 . Likewise, the coefficient on secret intervention is generally significant but positive for both currencies. Bundesbank intervention is significant and differs in sign over the two currencies. BOJ intervention is also significant and positive for the $\$ / Y$ en rate.

Tables 5a and $5 b$ present estimates over the post-Louvre subsample, starting in late February 1987 through December 1991. The three GARCH parameters and the holiday dummy variable continue to be statistically significant over this period for the daily data. In the weekly tests the coefficient on the conditional variance term is significant and about .8 for both the $\$ / D M$ and $\$ /$ Yen rates. The coefficient estimates on reported Fed intervention and the interest rate spread variable are significant and positive in both the daily and weekly models for the $\$ / D M$ rate. Secret Fed intervention is positive and significant in both the daily and weekly models for both currencies. In the weekly tests BOJ intervention is generally significant and negative for both currencies. The Engle and $\mathrm{Ng}$ (1992) diagnostic test indicates that there remains positive size bias in the weekly model for the \$/DM rate. Nelson's (1991) exponential GARCH (EGARCH) model provides 
an alternative specification that allows large innovations to have a larger impact on the conditional variance. ${ }^{30}$ EGARCH estimates of the conditional variance of the \$/DM rate over this period provided essentially identical results for the parameters of interest as those reported in the tables.

Tables $6 a$ and $6 \mathrm{~b}$ provide the final set of conditional variance equation estimates over the full period over which Fed data are available, 1985 through 1991. The daily GARCH parameters continue to be highly significant. Likewise the weekly lagged conditional variance and sample variance are now both significant. The holiday dummy is positive and always significant; the size of the coefficient suggests that exchange rate volatility increased by between 0.15 and 0.19 when the market reopened after a holiday. In the daily \$/DM models the interest rate spread variable is positive and significant. In the weekly. \$/Yen models both BOJ intervention and the exchange rate news variable are significantly positive. The reported Fed intervention variable is marginally significant and negative for both currencies in both the daily and

${ }^{30}$ An $\operatorname{EGARCH}(1,1)$ model replaces the first three terms in equation (6) with:

$$
\log v_{t}=\alpha_{0}+\alpha_{1} \log v_{t-1}+\phi_{1} \frac{e_{t-1}}{\sqrt{v_{t-1}}}+\phi_{2}\left[\frac{\left|\varepsilon_{t-1}\right|}{\sqrt{v_{t-1}}}-\sqrt{\frac{2}{\pi}}\right]
$$

By including the absolute value of the error term and by using logs, the EGARCH specification allows extreme innovations to have a larger impact on the next period conditional variance than the standard GARCH. 
weekly regressions. The average reported Fed dollar purchase and sale over this period is $\$ 213$ million, and the average sample variance of the daily percentage change in the $\$ / D M$ and $\$ /$ Yen rates is 0.601 and 0.472 , respectively. So the average effect of publicly known Fed intervention is to reduce daily volatility by approximately .06 for both currencies. A similar calculation for the weekly data suggests that reported Fed intervention reduces weekly volatility by approximately $.04 .^{31}$ Secret intervention is generally significantly positive in the regressions. The average daily secret Fed dollar purchase and sale over this period is $\$ 97$ million, so the average effect of secret Fed intervention is to increase daily volatility by approximately .02 for the \$/DM rate and .06 for the \$/Yen rate. On a weekly basis, secret Fed dollar purchases and sales averaged $\$ 138$ million, so the average effect of these operations is to increase weekly volatility by approximately .03 .

Overall, reported Fed intervention reduced exchange rate volatility over the period 1985 through 1991 . However, the subsample results suggest that reported Fed intervention reduced volatility in the period 1985 through 1988 and increased volatility over the period 1989 through 1991. Interestingly, in 1989 there is evidence from FOMC meeting minutes that it

31 The average reported weekly Fed purchase and sale over this period was $\$ 500$ million, and the average sample variance of the weekly percentage change in the $\$ / D M$ and $\$ / Y$ en rates was 2.74 and 2.37 , respectively. The average effect of publicly known Fed intervention on volatility is: $(\partial v / \partial \mathrm{I})(\mathrm{I} / v)$. 
was the US Treasury, and not the Fed, that dictated U.S. intervention policy. ${ }^{32}$ The minutes suggest that a number of the Fed Board members were uncomfortable with the heavy dollar selling intervention operations in 1989 , because Fed monetary policy was relatively contractionary during this period. Governors Angell and Johnson, in particular, were concerned that the Fed was sending the market mixed signals. ${ }^{33}$ Reported Bundesbank intervention consistently reduced daily exchange rate volatility over the period 1985 through 1988. Reported Bundesbank intervention also reduced volatility in the weekly $\$ /$ Yen data. But Bundesbank intervention increased volatility in the weekly \$/DM rate over the period 1985 through 1988. Fed and Bundesbank intervention operations that were not picked up by the financial press consistently increased volatility over all the periods for both currencies. The sign and significance of the intervention variables measured in magnitudes or dummy variable form were quite similar. This result confirms that just the presence of a central bank in the foreign exchange market influences volatility.

The results from the various conditional variance equations indicate that intervention and exchange rate volatility are often correlated, but it may

${ }^{32}$ In the US, the Treasury department has official jurisdiction over foreign exchange intervention policy. In practice the Treasury Department and the Fed typically jointly decide when the US should be in the market, but on occasion a decision may be made by Treasury over the objections of the Fed. Even though the Treasury can mandate intervention policy, it is the Federal Reserve Bank of New York that actually implements the policy.

${ }^{33}$ Kaminsky and Lewis (1993) also make this point. 
be that volatility causes intervention, rather than the other way around. This gets us back to the issue of whether intervention is truly an exogenous signal, or whether it is based on past exchange rate changes. Granger's (1969) causality regressions provide a test for this possibility. One variable Grangercauses another, if forecasts of the second variable can be improved by using past observations of the first variable in addition to past observations of the second variable. Tables $7 \mathrm{a}$ and $7 \mathrm{~b}$ present $\mathrm{F}$-statistics from a series of Granger-causality tests using reported and secret intervention magnitudes, the intervention dummy variables, and the news and interest rate spread variables in separate regressions. ${ }^{34}$ The tests regress each explanatory variable on its own past lags and past lags of the conditional variance from the GARCH models. The null hypothesis is that all the lags of the conditional variance are equal to zero. The F-statistics reported in the table suggest that volatility does not Granger-cause the reported intervention variables in either magnitude or dummy variable form. This is also the case for the news and interest rate spread variables. However, this hypothesis is often rejected for secret Fed intervention in subperiod (3), the post-Louvre Accord subsample. This evidence suggests that the Fed entered the market secretly when the foreign

34 Alternative causality tests including a time trend and using Sims (1972) methodology and the Geweke, Meese, and Dent (1982) serial correlation correction provided qualitatively similar results as those presented, and are therefore not included. 
exchange market was volatile over this period. This result will be the subject of further investigation.

\section{Conclusions}

The results in the previous section suggest that exchange rate policy variables belong in daily GARCH models of the exchange rate. Changes in relative contemporaneous monetary policy and intervention policy were often found to influence the conditional variance of exchange rates. Grangercausality tests, moreover, suggest that it is not volatility that causes intervention. However, the tests suggest that volatility may make the Fed more likely to keep its intervention secret.

One of the more strprising results in the paper is that intervention need not be publicly known in order that it influence volatility. Secret interventions were generally found to increase volatility. This result provides evidence in support of the Diebold and Nerlove (1989) hypothesis that the more ambiguous are signals, the higher is volatility.

The evidence provided in this paper suggests that intervention had mixed effects on volatility. The regression estimates suggest that secret central bank exchange rate policy did increase volatility, but secret interventions make up less than $20 \%$ of all intervention operations. Reported central bank intervention over the full period generally led to a reduction in both daily and weekly exchange rate volatility. Overall, therefore, intervention policy in the 1980s did not increase the volatility of foreign exchange rates. 
TABLE 1

\$IDM AND S/YEN EXCHANGE RATE STATISTICS

SMPL.

$\overline{\text { (1) }}_{\text {(2) }}^{\mathrm{DAILY}}$

(4)

$\frac{\text { WEEKLY }}{(1)} \cdot \frac{}{\text { (3) }} \cdot \frac{}{\text { (4) }}$

VARIABLE : $\mathrm{S}$, 9am spot \$/DM exchange rate

$\begin{array}{lllllllll}\text { mean } & 0.411 & 0.484 & 0.578 & 0.527 & 0.410 & 0.482 & 0.578 & 0.528 \\ \text { variance } & 0.005 & 0.009 & 0.002 & 0.008 & 0.005 & 0.009 & 0.002 & 0.009 \\ \text { skewness } & 0.068 & -0.546^{* *} & \mathbf{0 . 5 4 2 * *} & -0.877^{* *} & 0.058 & -0.534^{* *} & 0.523^{* *} & -0.883 * * \\ \text { kurtosis } & -1.215^{* *} & -1.028 * * & -0.265 \dagger & \mathbf{0 . 0 5 3} & -1.223^{*} & -1.039^{* *} & -0.248 & 0.083\end{array}$

VARIABLE : $\triangle(\operatorname{lnS})$ daily or weetly percentage change in the 9am spot \$/DM exchange rate

\begin{tabular}{|c|c|c|c|c|c|c|c|c|}
\hline mean & 0.102 & 0,058 & 0.015 & 0.042 & 0.513 & 0.291 & 0.077 & 0.209 \\
\hline Veriance & 0.783 & 0.599 & 0.518 & 0,601 & 3.428 & 2.665 & 2.446 & 2.748 \\
\hline skewness & $0.578 * *$ & $0.449 * 4$ & $-0.127 \dagger$ & $0.222 * *$ & 0.222 & $0.292 \dagger$ & 0.094 & 0.104 \\
\hline kurtosis & $3.269 * *$ & $3.562 * 4$ & $1.448 *+$ & $2.627^{* 4}$ & 0.355 & $0.639 \dagger$ & 0.013 & 0.345 \\
\hline $\begin{array}{l}x \\
Q_{a n}(\pi)\end{array}$ & $\begin{array}{l}10 \\
20.442 *\end{array}$ & $\begin{array}{l}20 \\
28.043\end{array}$ & 25 & 35 & 10 & 10 & 10 & 10 \\
\hline$Q_{0,1}(x)$ & 12.549 & $95.773 * 4$ & $116.461^{*+4}$ & $\begin{array}{c}36.247 \\
135.338 \div 4\end{array}$ & $\begin{array}{r}13.293 \\
5.784\end{array}$ & $\begin{array}{r}9.686 \\
14.837\end{array}$ & $\begin{array}{l}16.929 \dagger \\
17.675 \dagger\end{array}$ & $\begin{array}{l}16.908 \dagger \\
21.26 \mathrm{I}^{\circ}\end{array}$ \\
\hline
\end{tabular}

VARTABLE : $s, 9$ am spot $\$ / Y e n$ exchange rote

$\begin{array}{lcccccccc}\text { mean } & 0.518 & 0.624 & 0.731 & 0.665 & 0.518 & 0.622 & 0.731 & 0.666 \\ \text { variance } & 0.009 & 0.019 & 0.002 & 0.014 & 0.009 & 0.018 & 0.002 & 0.013 \\ \text { skewness } & -0.025 & -0.415^{* *} & -0.107 & -1.108 * * & -0.015 & -0.413^{*} & -0.127 & -1.120^{* *} \\ \text { kurtosis } & -1.612^{* *} & -1.095^{* *} & -0.871^{* *} & 0.236^{*} & -1.618^{* *} & -1.093^{* *} & -0.826^{* *} & 0.283\end{array}$

VARIABLE : $\Delta(\operatorname{lnS})$ daily or weekly percentage change in the 9an spot $\$ /$ Yen exchange rile

\begin{tabular}{|c|c|c|c|c|c|c|c|c|}
\hline mean & 0.092 & 0.069 & 0.017 & 0.040 & 0.458 & 0.351 & 0.076 & 0.188 \\
\hline variance & 0.460 & 0.462 & $0.47 \mathrm{~g}$ & 0.472 & 2.732 & 2.416 & 2.227 & 2,378 \\
\hline skewness & $0.609 * *$ & $0.262^{* 4}$ & $0.253^{4+4}$ & $0.351^{* *}$ & $0.979 * 4$ & $0.635^{* *}$ & 0.041 & $0,419 \mathrm{~km}$ \\
\hline kurtosis & $4.551^{\phi 4}$ & $3.351^{\circ}$ & $2.354 * *$ & $3.005^{* *}$ & $2.603 * 4$ & $2.208 * *$ & $0.610^{*}$ & $1.635 * *$ \\
\hline $\begin{array}{l}Q_{\Delta 3}(\pi) \\
Q_{\Delta 1}(x)\end{array}$ & $\begin{array}{l}28.144^{* *} \\
52.502^{* *}\end{array}$ & $\begin{array}{l}33.006^{*} \\
91.006^{*} *\end{array}$ & $\begin{array}{c}38.745 * \\
157.863 * *\end{array}$ & $\begin{array}{c}45.651 \\
173.896 \ldots *\end{array}$ & 4.918 & 6.897 & $17.158 \dagger$ & {$[1.74]$} \\
\hline & & & $137.0003-4$ & & 9.736 & 13.591 & $14.80 \mathrm{~J}$ & $20.521 *$ \\
\hline
\end{tabular}

\section{DAILY - \$/DM}

$0.997081 \quad 0.997081$

$0.994137-0.005630$

$0.991186-0.002909$

$0.988296 \quad 0.009135$

\begin{tabular}{lr}
\multicolumn{1}{c}{ SAM } \\
DAIIY $-\$ / Y$ EN \\
0.9973744 & 0.997374 \\
0.9947579 & 0.000408 \\
0.9920568 & -0.174363 \\
0.9893733 & 0.001933
\end{tabular}

SAMPLE 85-91

$\begin{array}{lc}\text { WEEKLY - \$DM } \\ \text { WES } \\ 0.9857226 & 0.985722 \\ 0.9725221 & 0.030795 \\ 0.9584551 & -0.035871 \\ 0.9447408 & 0.003079\end{array}$

$\begin{array}{cc}\text { WEEKLY } & -\$ / Y E N \\ 0.9872582 & 0.987258 \\ 0.9743689 & -0.012242 \\ 0.9611085 & -0.021148 \\ 0.9468905 & -0.04441\end{array}$

The skewness and kurtosis statistica are normalized so that a value of 0 corresponds to the normal distribulion. $Q_{\Delta}(x)$ pertains to the Box-Pierce $Q$-statistic teat for high-order serial comelation in $\Delta \mathrm{s}_{\mathrm{i}} \mathrm{x}$ is the number of correlations tested. $f$ denotes significance al the $90 \%$ level; * denoles significance at the $95 \%$ level; $*$ denotes significance al the $99 \%$ level. Sample (1) is 1/85-2/87 (Pre-Louvre Accord); anmple (2) is 1/85-12/88; sample (3) is 3/87-12/91 (Post-Louvre Accord); sample (4) is 1/85-12/91 (full sample). 
TABLE 28

DALY EXCHANGE RATE GARCH MODEL: CONDITIONAL. MEAN EQUATION

$$
\begin{aligned}
\Delta s_{t}=\beta_{0}+\sum_{i=1}^{4} \beta_{1} D_{n}+\beta_{3} H_{t}+\beta_{6} I_{t-1}^{v s}+\beta_{7} I_{t}^{s B}+\beta_{t} I_{t-1}^{s}+ \\
\beta_{9} I_{t}^{\Delta O U}+\beta_{10} N_{t-1}+\beta_{11} \Delta I_{t-1}+\beta_{12} \sqrt{v_{t}}+c_{t}
\end{aligned}
$$

\begin{tabular}{|c|c|c|c|c|c|c|c|c|}
\hline \multirow[b]{2}{*}{ smpl } & \multicolumn{4}{|c|}{ S/DM } & \multicolumn{4}{|c|}{ \$ $/$ Yen } \\
\hline & (1) & (2) & (3) & (4) & (b) & $(2)$ & (3) & (4) \\
\hline abs & 533 & 1002 & 1208 & 1745 & 533 & 1002 & 1208 & 1745 \\
\hline$\beta_{0}$ & $\begin{array}{l}-0.173 \\
(0.155)\end{array}$ & $\begin{array}{l}-0.212 \\
(0.143)\end{array}$ & $\begin{array}{l}-0.109 \\
(0.106)\end{array}$ & $\begin{array}{l}-0.158 \\
(0.093) \dagger\end{array}$ & $\begin{array}{l}-0.176 \\
(0.088)^{*}\end{array}$ & $\begin{array}{l}-0.177 \\
(0.085)^{*}\end{array}$ & $\begin{array}{l}-0.003 \\
(0.068)\end{array}$ & $\begin{array}{l}-0.087 \\
(0.060)\end{array}$ \\
\hline$\Sigma \mathfrak{G}_{\mathrm{i}}$ & $\begin{array}{c}0.147 \\
(0.111)\end{array}$ & $\begin{array}{l}0.117 \\
(0.065) \dagger\end{array}$ & $\begin{array}{c}0.049 \\
(0.058)\end{array}$ & $\begin{array}{c}0.094 \\
(0.051) \dagger\end{array}$ & $\begin{array}{c}0.051 \\
(0.068)\end{array}$ & $\begin{array}{c}0.121 \\
(0.053)^{* t}\end{array}$ & $\begin{array}{c}0.048 \\
(0.051)\end{array}$ & $\begin{array}{c}0.079 \\
(0.041) \dagger\end{array}$ \\
\hline$\beta_{3}$ & $\begin{array}{c}0.213 \\
(0.158)\end{array}$ & $\begin{array}{l}-0.056 \\
(0.131)\end{array}$ & $\begin{array}{c}0.103 \\
(0.111)\end{array}$ & $\begin{array}{c}0.128 \\
(0.089)\end{array}$ & $\begin{array}{c}0.166 \\
(0.114)\end{array}$ & $\begin{array}{c}0.058 \\
(0.116)\end{array}$ & $\begin{array}{c}0.085 \\
(0.096)\end{array}$ & $\begin{array}{c}0.101 \\
(0.079)\end{array}$ \\
\hline$\beta_{6}$ & $\begin{array}{l}-1.522 \\
(0.430)^{\mathrm{nt}}\end{array}$ & $\begin{array}{c}0.077 \\
(0.046) \dagger\end{array}$ & $\begin{array}{c}0.327 \\
(0.142)^{*}\end{array}$ & $\begin{array}{c}0.354 \\
(0.191) \dagger\end{array}$ & $\begin{array}{l}-0.011 \\
(0.399)\end{array}$ & $\begin{array}{l}-0.003 \\
(0.298)\end{array}$ & $\begin{array}{c}0.274 \\
(0.115)^{*}\end{array}$ & $\begin{array}{l}0.366 \\
(0.193) \dagger\end{array}$ \\
\hline$\beta$, & $\begin{array}{c}0.714 \\
(0.780)\end{array}$ & $\begin{array}{c}1.132 \\
(0.405)^{* *}\end{array}$ & & & $\begin{array}{c}0.402 \\
(0.197)^{*}\end{array}$ & $\begin{array}{c}0.325 \\
(0.274)\end{array}$ & & \\
\hline$\beta_{1}$ & $\begin{array}{l}-0.181 \\
(1.977)\end{array}$ & $\begin{array}{c}1.243 \\
(0.605)^{*}\end{array}$ & $\begin{array}{c}1.343 \\
(0.649)^{*}\end{array}$ & $\begin{array}{c}1.324 \\
(0.600)^{*}\end{array}$ & $\begin{array}{c}0.512 \\
(1.608)\end{array}$ & $\begin{array}{c}0.854 \\
(0.579)\end{array}$ & $\begin{array}{c}1.179 \\
(0.676) \dagger\end{array}$ & $\begin{array}{l}1.114 \\
(0.623)^{\dagger}\end{array}$ \\
\hline$\beta_{9}$ & $\begin{array}{c}0.176 \\
(0.121)\end{array}$ & $\begin{array}{c}0.182 \\
(0.070)^{* *}\end{array}$ & $\begin{array}{c}0.125 \\
(0.069) \dagger\end{array}$ & $\begin{array}{c}0.111 \\
(0.056)^{*}\end{array}$ & $\begin{array}{c}0.003 \\
(0.119)\end{array}$ & $\begin{array}{c}0.179 \\
(0.072)^{*}\end{array}$ & $\begin{array}{c}0.237 \\
(0.068)^{* *}\end{array}$ & $\begin{array}{c}0.167 \\
(0.058)^{* *}\end{array}$ \\
\hline$\rho_{1 a}$ & $\begin{array}{l}-0.295 \\
(0.098)^{+4}\end{array}$ & $\begin{array}{l}-0.213 \\
(0.055)^{* *}\end{array}$ & $\begin{array}{l}-0.115 \\
(0.050)^{*}\end{array}$ & $\begin{array}{l}-0.149 \\
(0.043)^{* 4}\end{array}$ & $\begin{array}{l}-0.089 \\
(0.056)\end{array}$ & $\begin{array}{l}-0.145 \\
(0.045)^{* *}\end{array}$ & $\begin{array}{l}-0.139 \\
(0.049)^{* *}\end{array}$ & $\begin{array}{l}-0.124 \\
(0.037)^{* *}\end{array}$ \\
\hline$\beta_{! !}$ & $\begin{array}{l}-0.001 \\
(0.032)\end{array}$ & $\begin{array}{l}-0.004 \\
(0.026)\end{array}$ & $\begin{array}{c}0.004 \\
(0.009)\end{array}$ & $\begin{array}{l}-0.002 \\
(0.008)\end{array}$ & $\begin{array}{l}-0.003 \\
(0.029)\end{array}$ & $\begin{array}{c}0.018 \\
(0.016)\end{array}$ & $\begin{array}{c}0.008 \\
(0.007)\end{array}$ & $\begin{array}{c}0.007 \\
(0,006)\end{array}$ \\
\hline$\beta_{12}$ & $\begin{array}{c}0.196 \\
(0.141)\end{array}$ & $\begin{array}{l}0.342 \\
(0.127)^{4 *}\end{array}$ & $\begin{array}{c}0.174 \\
(0.144)\end{array}$ & $\begin{array}{l}0.205 \\
(0.116) \dagger\end{array}$ & $\begin{array}{c}0.313 \\
(0.108)^{n \star}\end{array}$ & $\begin{array}{l}0.3 B B \\
(0.125)^{* *}\end{array}$ & $\begin{array}{c}0.030 \\
(0.100)\end{array}$ & $\begin{array}{c}0.152 \\
(0.087) \dagger\end{array}$ \\
\hline
\end{tabular}

StandarL errors are in parentheses. $\uparrow$ denotes significance at the $90 \%$ level; * denotes significance at the $95 \%$ level; ** denotes significance at the 99 \% level. Sample (1) is 1/85-2/87 (Pre-Louvre Accord); sanple (2) is 1/85-12/88; sample (3) is 3/87-12/91 (Post-Louvre Accord); sample (4) is 1/85-12/91 (full sample). 
TABLE 2b

WEEKLY EXCHANGE RATE OARCH MODEL: CONDITIONAL MEAN EQUATJON

$$
\begin{aligned}
& \Delta s_{1}=\beta_{0}+\beta_{1} J_{t-j-1}^{\omega s}+\beta_{2} I_{r-j s}^{\Delta s}+\beta_{1} J_{r-j,-1}^{s} \\
& +\beta_{4} J_{t-j \mu}^{c a l}+\beta_{3} N_{t-j,-1}+\beta_{6} \Delta i_{t-1}+\beta_{7} \sqrt{v_{1}}+\varepsilon_{t}
\end{aligned}
$$

\begin{tabular}{|c|c|c|c|c|c|c|c|c|}
\hline \multirow[b]{2}{*}{ smpl] } & \multicolumn{4}{|c|}{ \$ $/ \mathrm{DM}$} & \multicolumn{4}{|c|}{$\$ / Y e n$} \\
\hline & (1) & (2) & (3) & (4) & (1) & (2) & (3) & (4) \\
\hline obs & 110 & 206 & 251 & 362 & 110 & 206 & 251 & 362 \\
\hline$\beta_{0}$ & $\begin{array}{l}-0.276 \\
(0.703)\end{array}$ & $\begin{array}{c}0.965 \\
(0.382)^{*}\end{array}$ & $\begin{array}{c}1.463 \\
(0.351)^{4 *}\end{array}$ & $\begin{array}{l}-0.119 \\
(0.521)\end{array}$ & $\begin{array}{l}-0.735 \\
(0.928)\end{array}$ & $\begin{array}{l}-2.330 \\
(1.274) t\end{array}$ & $\begin{array}{c}0.699 \\
(0.321)^{*}\end{array}$ & $\begin{array}{c}0.164 \\
(0.351)\end{array}$ \\
\hline$\beta_{1}$ & $\begin{array}{l}-0.069 \\
(0.039) \dagger\end{array}$ & $\begin{array}{l}-0.139 \\
(0.480)\end{array}$ & $\begin{array}{c}0.320 \\
(0.168) \uparrow\end{array}$ & $\begin{array}{c}0.596 \\
(0.283)^{*}\end{array}$ & $\begin{array}{l}-1.608 \\
(4.031)\end{array}$ & $\begin{array}{l}-0.133 \\
(0.600)\end{array}$ & $\begin{array}{c}0.553 \\
(0.304) \dagger\end{array}$ & $\begin{array}{c}0.749 \\
(0.318)^{*}\end{array}$ \\
\hline$\beta_{2}$ & $\begin{array}{c}3.174 \\
(1.284)^{*}\end{array}$ & $\begin{array}{l}2.130 \\
(0.607)^{* *}\end{array}$ & & & $\begin{array}{c}1.008 \\
(0.773)\end{array}$ & $\begin{array}{c}1.921 \\
(0.829)^{*}\end{array}$ & & \\
\hline $\boldsymbol{\beta}_{3}$ & $\begin{array}{c}3.000 \\
(1.005)^{*+*}\end{array}$ & $\begin{array}{c}4.451 \\
(2.728) \dagger\end{array}$ & $\begin{array}{c}0.323 \\
(1.641)\end{array}$ & $\begin{array}{c}0.753 \\
(1.186)\end{array}$ & $\begin{array}{c}4.104 \\
(5.016)\end{array}$ & $\begin{array}{c}5.077 \\
(2.939) \dagger\end{array}$ & $\begin{array}{c}0.128 \\
(1.805)\end{array}$ & $\begin{array}{c}0.843 \\
(1.646)\end{array}$ \\
\hline B. & $\begin{array}{l}-0.603 \\
(0.354) \dagger\end{array}$ & $\begin{array}{c}0.160 \\
(0.208)\end{array}$ & $\begin{array}{c}0.447 \\
(0.172)^{* *}\end{array}$ & $\begin{array}{c}0.282 \\
(0.214)\end{array}$ & $\begin{array}{l}-0.801 \\
(0.576)\end{array}$ & $\begin{array}{l}-0.19 .6 \\
(0.291)\end{array}$ & $\begin{array}{c}0.567 \\
(0.227)^{*}\end{array}$ & $\begin{array}{l}0.356 \\
(0.191) \dagger\end{array}$ \\
\hline$\beta_{s}$ & $\begin{array}{l}-0.324 \\
(0.302)\end{array}$ & $\begin{array}{l}-0.703 \\
(0.164)^{+4}\end{array}$ & $\begin{array}{l}-0.366 \\
(0.148)^{*}\end{array}$ & $\begin{array}{l}-0.339 \\
(0.138)^{*}\end{array}$ & $\begin{array}{l}-0.122 \\
(0.317)\end{array}$ & $\begin{array}{l}-0.279 \\
(0.177)\end{array}$ & $\begin{array}{l}-0.283 \\
(0.165) \dagger\end{array}$ & $\begin{array}{l}-0.247 \\
(0.151)\end{array}$ \\
\hline$\beta_{6}$ & $\begin{array}{l}-0.160 \\
(0.208)\end{array}$ & $\begin{array}{c}0.329 \\
(0.112)^{* 4}\end{array}$ & $\begin{array}{c}0.121 \\
(0.063) \dagger\end{array}$ & $\begin{array}{c}0.028 \\
(0.044)\end{array}$ & $\begin{array}{l}-0.146 \\
(0.351)\end{array}$ & $\begin{array}{l}-0.026 \\
(0.195)\end{array}$ & $\begin{array}{l}-0.003 \\
(0.043)\end{array}$ & $\begin{array}{c}0.023 \\
(0.042)\end{array}$ \\
\hline$\beta_{7}$ & $\begin{array}{c}0.272 \\
(0.327)\end{array}$ & $\begin{array}{c}0.274 \\
(0.163) \dagger\end{array}$ & $\begin{array}{l}-0.838 \\
(0.205)^{* *}\end{array}$ & $\begin{array}{c}0.254 \\
(0.317)\end{array}$ & $\begin{array}{c}0.629 \\
(0.678)\end{array}$ & $\begin{array}{c}1.849 \\
(0.725)^{4}\end{array}$ & $\begin{array}{l}-0.434 \\
(0.283)\end{array}$ & $\begin{array}{c}0.067 \\
(0.274)\end{array}$ \\
\hline
\end{tabular}

The time subseript $t-j, t-1$ denotes from time $1-j$ to time $1-1$, where $j=5$ days. Standard errors are in parentheses. $\dagger$ denoles signilicance at the $90 \%$ level; * degotes significance al the $95 \%$ level; ** denotes significance at the $99 \%$ level. Sample (1) is 1/85-2/87 (Pro-Louvre Accord); semple (2) is 1/85-12/88; ssmple (3) is 3/87-12/91 (Post Louvre Accord); sample (4) is 1/85-12/91 (full sample). 
TABLE 3a

DALY EXCHANGE RATE GARCH MODELS: CONDTTIONAL VARLANCE EQUATIONS SAMPLE: 1/85-2/87, 533 obs (Pre-Louvre Accord)

$$
\begin{aligned}
v_{t}=\alpha_{0}+\alpha_{1} \nu_{t-1}+\alpha_{2} \varepsilon_{t-1}^{2}+\phi_{1} H_{1} & +\psi_{1}\left|I_{t-1}^{v s}\right|+\psi_{2}\left|f_{t}^{s t}\right|+\psi_{j}\left|I_{t-1}^{s}\right| \\
& +\psi_{1}\left|I_{t}^{s u_{1}}\right|+\psi_{s}\left|N_{r-1}\right|+\psi_{6} \Delta i_{t-1}
\end{aligned}
$$

\begin{tabular}{|c|c|c|c|c|c|c|}
\hline & \multicolumn{3}{|c|}{$\$ / \mathrm{DM}$} & \multicolumn{3}{|c|}{ SIYEN } \\
\hline & BASIC & $\begin{array}{l}\text { MAGNI- } \\
\text { TUDES }\end{array}$ & $\begin{array}{c}\text { DUMMY } \\
\text { VARS }\end{array}$ & BASIC & $\begin{array}{l}\text { MAGNI- } \\
\text { TUDES }\end{array}$ & $\begin{array}{c}\text { DUMMY } \\
\text { VARS }\end{array}$ \\
\hline$\sigma_{0}$ & $\begin{array}{c}0.071 \\
(0.03 \mathrm{~L})^{*}\end{array}$ & $\begin{array}{c}0.016 \\
(0.019)\end{array}$ & $\begin{array}{c}0.027 \\
(0.024)\end{array}$ & $\begin{array}{c}0.02 B \\
(0.012)^{*}\end{array}$ & $\begin{array}{c}0.002 \\
(0.014)\end{array}$ & $\begin{array}{c}0.021 \\
(0.018)\end{array}$ \\
\hline$\alpha_{1}$ & $\begin{array}{c}0.830 \\
(0.058)^{* *}\end{array}$ & $\begin{array}{c}0.924 \\
(0.026)^{* *}\end{array}$ & $\begin{array}{l}0.905 \\
(0.031)^{\text {nin }}\end{array}$ & $\begin{array}{c}0.773 \\
(0.053)^{-1}\end{array}$ & $\begin{array}{c}0.787 \\
(0.047)^{* \star}\end{array}$ & $\begin{array}{c}0.768 \\
(0.052)^{ \pm *}\end{array}$ \\
\hline$a_{2}$ & $\begin{array}{c}0.086 \\
(0.041)^{*}\end{array}$ & $\begin{array}{c}0.035 \\
(0.021) \dagger\end{array}$ & $\begin{array}{c}0.054 \\
(0.026)^{*}\end{array}$ & $\begin{array}{c}0.172 \\
(0.059)^{4 *}\end{array}$ & $\begin{array}{c}0.146 \\
(0.050)^{* *}\end{array}$ & $\begin{array}{l}0.129 \\
(0.046)^{* *}\end{array}$ \\
\hline$\phi_{i}$ & $\begin{array}{c}0.050 \\
(0.149)\end{array}$ & $\begin{array}{c}0.171 \\
(0.121)\end{array}$ & $\begin{array}{c}0.074 \\
(0.142)\end{array}$ & $\begin{array}{c}0.201 \\
(0.120) \dagger\end{array}$ & $\begin{array}{c}0.123 \\
(0.076)\end{array}$ & $\begin{array}{c}0.121 \\
(0.072) \dagger\end{array}$ \\
\hline$\psi_{1}$ & & $\begin{array}{l}-0.246 \\
(0.145) \dagger\end{array}$ & $\begin{array}{l}-0.147 \\
(0.081) \dagger\end{array}$ & & $\begin{array}{l}-0.586 \\
(0.338) \dagger\end{array}$ & $\begin{array}{l}-0.082 \\
(0.059)\end{array}$ \\
\hline$\psi_{2}$ & & $\begin{array}{l}-0.161 \\
(0.235)\end{array}$ & $\begin{array}{l}-0.093 \\
(0.050) \dagger\end{array}$ & & $\begin{array}{l}-0.274 \\
(0.082)^{4 *}\end{array}$ & $\begin{array}{l}-0.090 \\
(0.029)^{*+}\end{array}$ \\
\hline$\psi_{3}$ & & $\begin{array}{c}1.511 \\
(1.261)\end{array}$ & $\begin{array}{c}0.037 \\
(0.080)\end{array}$ & & $\begin{array}{c}0.108 \\
(1.099)\end{array}$ & $\begin{array}{c}0.217 \\
(0.106)^{*}\end{array}$ \\
\hline$\psi$ & & $\begin{array}{l}-0.098 \\
(0.071)\end{array}$ & $\begin{array}{c}0.147 \\
(0.107)\end{array}$ & & $\begin{array}{c}0.192 \\
(0.128)\end{array}$ & $\begin{array}{l}-0.030 \\
(0.040)\end{array}$ \\
\hline$\psi$ & & $\begin{array}{c}0.072 \\
(0.051)\end{array}$ & $\begin{array}{c}0.055 \\
(0.05 .8)\end{array}$ & & $\begin{array}{l}-0.027 \\
(0.098)\end{array}$ & $\begin{array}{c}0.003 \\
(0.045)\end{array}$ \\
\hline$\psi_{s}$ & & $\begin{array}{l}-0.008 \\
(0.006)\end{array}$ & $\begin{array}{l}-0.004 \\
(0.009)\end{array}$ & & $\begin{array}{l}-0.017 \\
(0.007)\end{array}$ & $\begin{array}{l}-0.014 \\
(0.007) \neq\end{array}$ \\
\hline$n$ & $\begin{array}{c}7.043 \\
(2.079)^{\text {*k }}\end{array}$ & $\begin{array}{c}6.511 \\
(1.886)^{\text {\#* }}\end{array}$ & $\begin{array}{l}5.961 \\
(1.462)^{* *}\end{array}$ & $\begin{array}{c}4.293 \\
(0.756)^{* *}\end{array}$ & $\begin{array}{l}4.321 \\
(0.739)^{4 *}\end{array}$ & $\begin{array}{l}4.265 \\
(0.705)^{* *}\end{array}$ \\
\hline $\ln 2$ & -361.3 & -348.9 & -342.6 & -186.3 & -169.7 & -165.6 \\
\hline$\rho$ & 16 & 119 & 57 & 17 & 21 & 15 \\
\hline$Q_{t}(10)$ & $16.948 \dagger$ & $22.947 * *$ & $26.197^{4 *}$ & 14.451 & 14.908 & $16.647 \dagger$ \\
\hline Q.(10) & 6.313 & 3.881 & 2.884 & 2,643 & 2.437 & 1.492 \\
\hline
\end{tabular}

$n$ is the degrees of freedom parameter in the Student I distribution. $\rho$ is the number of convergence jterations. 
TABLE 3b

WEEKLY EXCHANGE RATE OARCH MODELS: CONDITIONAL VARIANCE EQUATIONS SAMPLE: 1/85-2/87, 110 obs ( Pre-Louvre Accord)

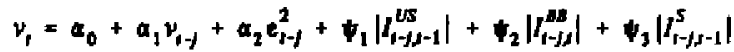

$$
\begin{aligned}
& +\nabla_{4}\left|t_{1-j}^{D 0 J}\right|+\phi_{3}\left|N_{1-j-1}\right|+\phi_{6} \Delta i_{1-1}
\end{aligned}
$$

\begin{tabular}{lcc} 
& \$DM & \\
\hline BASIC & MAGNI- & DUMMY \\
& TUDES & VARS
\end{tabular}

\begin{tabular}{lll} 
& \$FEN & \\
\hline BASIC & MAGNI- & DUMMY \\
& TUDES & VARS
\end{tabular}

\begin{tabular}{|c|c|c|c|c|c|c|}
\hline$\alpha_{0}$ & $\begin{array}{c}0.619 \\
(0.460)\end{array}$ & $\begin{array}{c}0.322 \\
(0.128)^{4}\end{array}$ & $\begin{array}{c}0.184 \\
(0.225)\end{array}$ & $\begin{array}{c}1.251 \\
(0.748) \dagger\end{array}$ & $\begin{array}{c}0.147 \\
(0.536)\end{array}$ & $\begin{array}{c}0.511 \\
(0.837)\end{array}$ \\
\hline$\alpha_{1}$ & $\begin{array}{c}0.641 \\
(0.211)^{* 4}\end{array}$ & $\begin{array}{c}0.971 \\
(0.076)^{+*}\end{array}$ & $\begin{array}{c}0.949 \\
(0.062)^{+*}\end{array}$ & $\begin{array}{c}0.242 \\
(0.308)\end{array}$ & $\begin{array}{l}0.348 \\
(0.129)^{* *}\end{array}$ & $\begin{array}{c}0.521 \\
(0.171)^{4 *}\end{array}$ \\
\hline$\alpha_{2}$ & $\begin{array}{c}0.194 \\
(0.148)\end{array}$ & $\begin{array}{c}0.108 \\
(0.099)\end{array}$ & $\begin{array}{c}0.055 \\
(0.050)\end{array}$ & $\begin{array}{c}0.302 \\
(0.137)\end{array}$ & $\begin{array}{c}0.123 \\
(0.109)\end{array}$ & $\begin{array}{c}0.046 \\
(0.060)\end{array}$ \\
\hline$\psi_{1}$ & & $\begin{array}{l}-1.278 \\
(1.349)\end{array}$ & $\begin{array}{c}0.397 \\
(0.333)\end{array}$ & & $\begin{array}{l}+3.779 \\
(3.997)\end{array}$ & $\begin{array}{l}-1.559 \\
(1.095)\end{array}$ \\
\hline$\psi_{2}$ & & $\begin{array}{c}1.803 \\
(0.611)^{*}\end{array}$ & $\begin{array}{c}0.093 \\
(0.407)\end{array}$ & & $\begin{array}{l}-2.311 \\
(1.106)^{*}\end{array}$ & $\begin{array}{l}-0.999 \\
(0.795)\end{array}$ \\
\hline$\psi$ & & $\begin{array}{c}5.660 \\
(3.398) t\end{array}$ & $\begin{array}{c}2.896 \\
(1.193)\end{array}$ & & $\begin{array}{l}12.711 \\
(7.232) \dagger\end{array}$ & $\begin{array}{c}1.061 \\
(0.617) \dagger\end{array}$ \\
\hline$\psi_{4}$ & & $\begin{array}{l}-0.295 \\
(0.235)\end{array}$ & $\begin{array}{l}-0.483 \\
(0.567)\end{array}$ & & $\begin{array}{c}0.718 \\
(1.135)\end{array}$ & $\begin{array}{c}0.972 \\
(0.793)\end{array}$ \\
\hline$\psi_{3}$ & & $\begin{array}{l}0.147 \\
(0.299)\end{array}$ & $\begin{array}{c}0.481 \\
(0.348)\end{array}$ & & $\begin{array}{c}0.942 \\
(0.622)\end{array}$ & $\begin{array}{c}1.389 \\
(0.623)^{*}\end{array}$ \\
\hline$\psi_{s}$ & & $\begin{array}{c}0.181 \\
(0.008)^{+4}\end{array}$ & $\begin{array}{c}0.159 \\
(0.023)^{+4}\end{array}$ & & $\begin{array}{c}0.481 \\
(0.314)\end{array}$ & $\begin{array}{c}0.011 \\
(0.413)\end{array}$ \\
\hline $\ln \mathrm{L}$ & -119.2 & -100.2 & -101.9 & -103.4 & -88.8 & -99.1 \\
\hline$\rho$ & 21 & 17 & 18 & 25 & 24 & 15 \\
\hline$Q_{4}(10)$ & 10.501 & 11.512 & 11.024 & 5.216 & 5.341 & 7.532 \\
\hline $\begin{array}{l}Q_{1}(10) \\
E \& N\end{array}$ & $\begin{array}{l}5.048 \\
n s\end{array}$ & $\begin{array}{l}8.588 \\
\mathrm{~ns}\end{array}$ & $\begin{array}{l}8.213 \\
\mathrm{~ns}\end{array}$ & $\begin{array}{l}3.672 \\
\mathrm{ng}\end{array}$ & $\begin{array}{l}6.774 \\
\text { ns }\end{array}$ & $\begin{array}{l}2.395 \\
n 5\end{array}$ \\
\hline
\end{tabular}

Standerd ersors are in parentheses, † denotes significence at the $90 \%$ level; denotea significance at the $95 \mathrm{~g}$ level: ** denotes significance at the $99 \%$ level. In $\mathrm{L}$ is the value of the log liketihood funclion, $\rho$ is the number of convergence iteratious, $Q$ is the Box-Piefe $Q$-statistic for the standardized residuals, and E\&N denotes whelher any coeflicient from the Engle and $\mathrm{Ng}$ (1992) disguostic regression indicates that the GARCH restrictions are violated. 
TABLE 4a

DAILY EXCHANGE RATE GARCH MODELS: CONDITIONAL VARIANCE EQUATIONS SAMPLE: $1 / 85-12 / 88,1002$ obs

$$
\begin{aligned}
v_{s}=\alpha_{0}+\alpha_{1} v_{r-1}+\alpha_{2} e_{t-1}^{2}+\phi_{1} H_{t} & +\psi_{1}\left|I_{r-1}^{s t}\right|+\psi_{2}\left|I_{t}^{s \Delta}\right|+\psi_{3}\left|I_{t-1}^{s}\right| \\
& +\psi_{4}\left|I_{t}^{s 0 s}\right|+\psi_{s}\left|N_{t-1}\right|+\psi_{s} \Delta i_{t-1}
\end{aligned}
$$

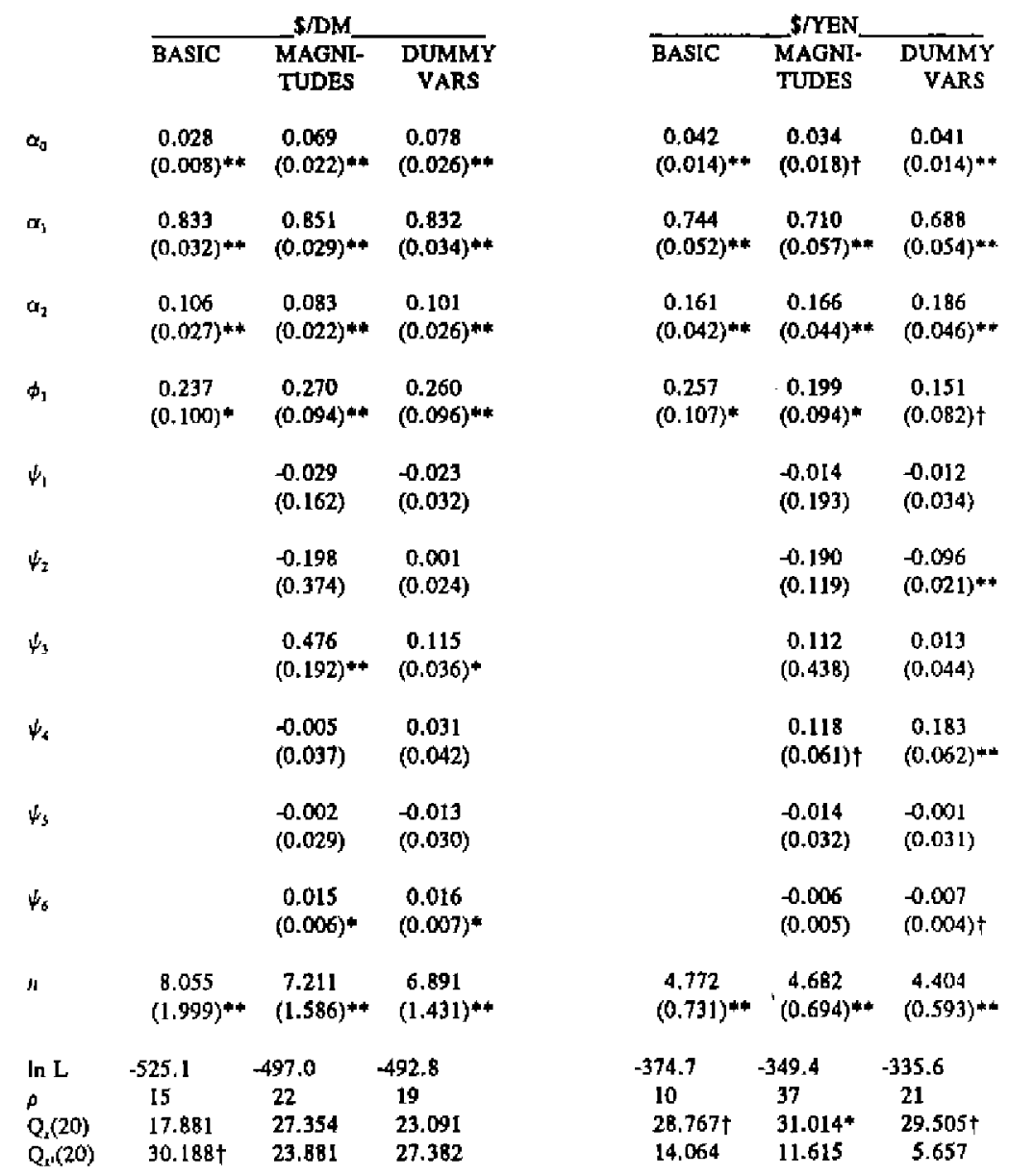

$n$ is the degrees of freedom parameter in the Student $t$ distribution. $\rho$ is the number of convergence iteralinns. 
TABLE 4b

WEEKL,Y EXCHANGE RATE GARCH MODELS: CONDITIONAL VARIANCE EQUATIONS SAMPLE: $1 / 85-12 / 88,206 \mathrm{obs}$

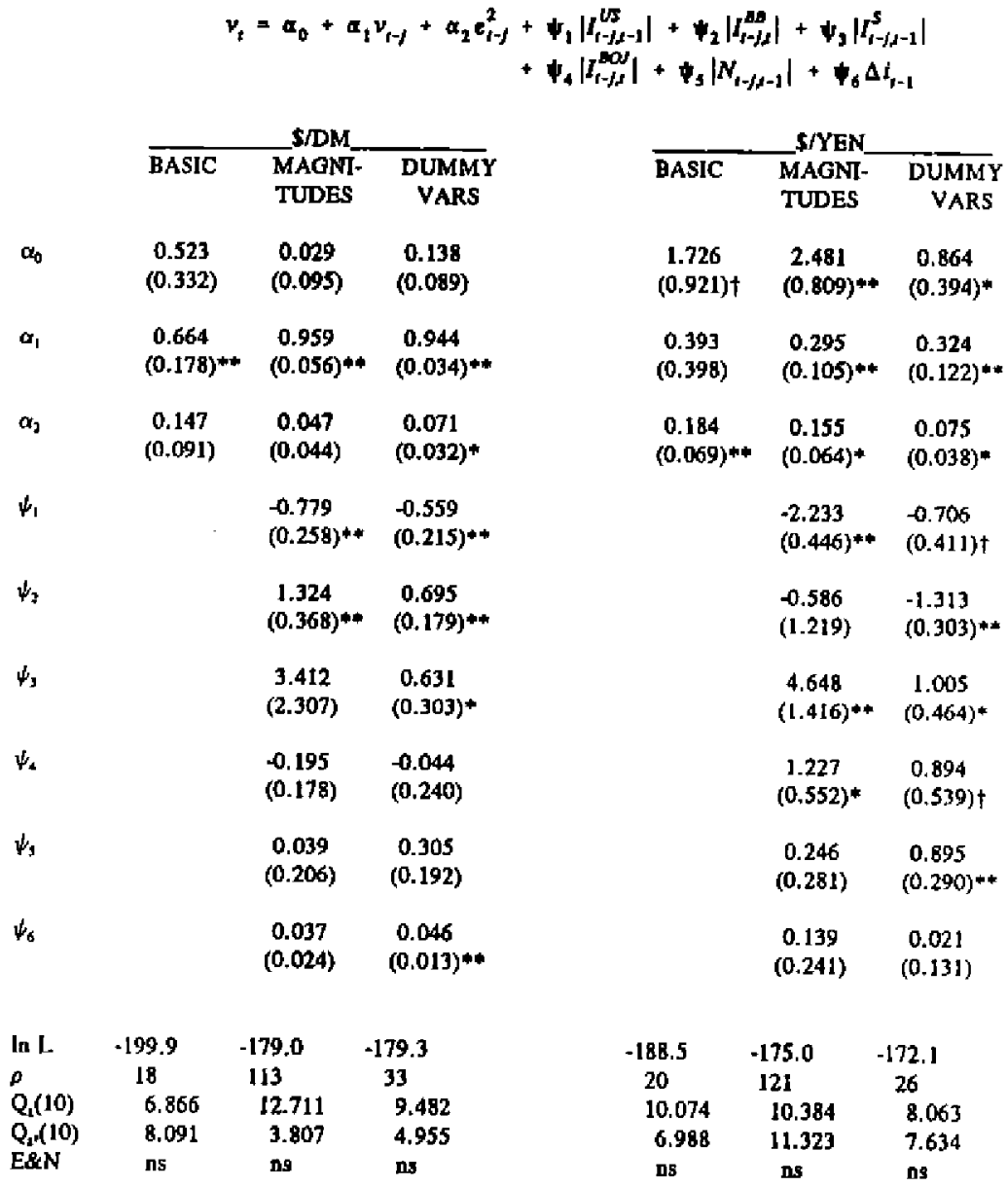

Standard errors are in parentheses. † denotes sigaificance at the $90 \%$ level; denotes significance al the $95 \%$ level; ** denotes significance at the $99 \%$ level. In $\mathrm{L}$ is the value of the log likelihood function, $\rho$ is the number of convergence iterations, $Q$ is the Box-Pierce Q-statistic for the standardized residuals, and E\&N denotes whether any coefficient from the Engle and $\mathrm{Ng}$ (1992) diaguostic regression indicates that the GARCH resirictions are vjolated. 
TABLE 59

DAILY EXCHANGE RATE OARCH MODELS: CONDITIONAL VARLANCE EQUATIONS

SAMPLE: 3/87-12/91, 1208 obs ( Post-Louvre Accord)

$$
\begin{aligned}
& v_{r}=\alpha_{0}+\alpha_{1} v_{t-1}+\alpha_{2} e_{t-1}^{2}+\phi_{1} H_{1}+\psi_{1}\left|I_{t-1}^{L s}\right|+\psi_{2}\left|I_{t}^{s t}\right|+\psi_{3}\left|I_{t-1}^{s}\right| \\
& +\psi_{4}\left|I_{5}^{100}\right|+\psi_{5}\left|N_{t-1}\right|+\psi_{6} \Delta l_{t-1}
\end{aligned}
$$

$\begin{array}{lll}\text { BASIC } & \begin{array}{c}\text { MAGNI- } \\ \text { TUDES }\end{array} & \begin{array}{c}\text { DUMMY } \\ \text { VARS }\end{array}\end{array}$

\begin{tabular}{|c|c|c|c|c|c|c|}
\hline$\alpha_{0}$ & $\begin{array}{c}0.031 \\
(0.010)^{* *}\end{array}$ & $\begin{array}{c}0.061 \\
(0.019)^{* * *}\end{array}$ & $\begin{array}{c}0.054 \\
(0.017)^{\star 4}\end{array}$ & $\begin{array}{c}0.022 \\
(0.007)^{+\infty}\end{array}$ & $\begin{array}{c}0.014 \\
(0,006)^{*}\end{array}$ & $\begin{array}{c}0.013 \\
(0.006)^{*}\end{array}$ \\
\hline$a_{1}$ & $\begin{array}{l}0.828 \\
(0.035)^{* * *}\end{array}$ & $\begin{array}{c}0.783 \\
(0.049)^{* 4}\end{array}$ & $\begin{array}{l}0.791 \\
(0.047)^{* *}\end{array}$ & $\begin{array}{c}0.846 \\
(0.031)^{* *}\end{array}$ & $\begin{array}{c}0.843 \\
(0.029)^{4 *}\end{array}$ & $\begin{array}{c}0.839 \\
(0.030)^{* *}\end{array}$ \\
\hline$\alpha_{2}$ & $\begin{array}{c}0.098 \\
(0.024)^{*+*}\end{array}$ & $\begin{array}{l}0.075 \\
(0.023)^{* *}\end{array}$ & $\begin{array}{c}0.082 \\
(0.024)^{m+*}\end{array}$ & $\begin{array}{c}0.104 \\
(0.024)^{* *}\end{array}$ & $\begin{array}{l}0.091 \\
(0.023)^{* *}\end{array}$ & $\begin{array}{l}0.098 \\
(0.023)^{* *}\end{array}$ \\
\hline$\phi_{1}$ & $\begin{array}{c}0.183 \\
(0.082)^{*}\end{array}$ & $\begin{array}{c}0.224 \\
(0.089)^{*}\end{array}$ & $\begin{array}{c}0.230 \\
(0.091)^{*}\end{array}$ & $\begin{array}{c}0.123 \\
(0.067) \uparrow\end{array}$ & $\begin{array}{c}0.149 \\
(0.066)^{*}\end{array}$ & $\begin{array}{c}0.153 \\
(0.069)^{*}\end{array}$ \\
\hline$\psi_{1}$ & & $\begin{array}{c}0.333 \\
(0.137)^{*}\end{array}$ & $\begin{array}{l}0.049 \\
(0.027) \dagger\end{array}$ & & $\begin{array}{c}0.162 \\
(0.107)\end{array}$ & $\begin{array}{c}0.012 \\
(0.024)\end{array}$ \\
\hline$\psi_{2}$ & & NA & NA & & NA & NA \\
\hline$\psi_{3}$ & & $\begin{array}{c}0.465 \\
(0.175)^{* *}\end{array}$ & $\begin{array}{c}0.222 \\
(0.032)^{*}\end{array}$ & & $\begin{array}{c}0.596 \\
(0.194)^{+*}\end{array}$ & $\begin{array}{c}0.103 \\
(0,021) t\end{array}$ \\
\hline$\psi_{4}$ & & $\begin{array}{c}0.01 B \\
(0.040)\end{array}$ & $\begin{array}{c}0.027 \\
(0.042)\end{array}$ & & $\begin{array}{c}0.016 \\
(0.037)\end{array}$ & $\begin{array}{c}0.037 \\
(0.038)\end{array}$ \\
\hline$\psi$ & & $\begin{array}{l}-0.005 \\
(0.026)\end{array}$ & $\begin{array}{c}0.001 \\
(0.026)\end{array}$ & & $\begin{array}{c}0.042 \\
(0.026)\end{array}$ & $\begin{array}{c}0.043 \\
(0.027) \dagger\end{array}$ \\
\hline$\psi_{n}$ & & $\begin{array}{c}0.008 \\
(0.002)^{\star *}\end{array}$ & $\begin{array}{c}0.008 \\
(0.002)^{* *}\end{array}$ & & $\begin{array}{c}0.001 \\
(0.001)\end{array}$ & $\begin{array}{c}0.001 \\
(0.001)\end{array}$ \\
\hline$n$ & $\begin{array}{l}10.558 \\
(2.672)^{* *}\end{array}$ & $\begin{array}{l}12.723 \\
(4.020)^{\text {*h }}\end{array}$ & $\begin{array}{l}11.867 \\
(3.644)^{+* *}\end{array}$ & $\begin{array}{l}5.777 \\
(1.174)^{4 * *}\end{array}$ & $\begin{array}{l}6.218 \\
(1.366)^{+*}\end{array}$ & $\begin{array}{c}6.02 \mathrm{~L} \\
(\mathrm{I} .2 \mathrm{BL})^{* * *}\end{array}$ \\
\hline $\ln L$ & -567.2 & -546.5 & -550.7 & -486.4 & -462.0 & -463.7 \\
\hline$\rho$ & 11 & 17 & 17 & 15 & 17 & 16 \\
\hline$Q_{x}(25)$ & $38.114^{*}$ & 33.148 & 33.707 & $45.218^{* *}$ & $34.728 \dagger$ & $37.963 *$ \\
\hline$Q_{r}(25)$ & 24.699 & 19.677 & 22.402 & 19.367 & 15.204 & 15.986 \\
\hline
\end{tabular}

\begin{tabular}{lcc}
\hline BASIC & $\begin{array}{c}\text { MAGNI- } \\
\text { TUDES }\end{array}$ & $\begin{array}{c}\text { DUMMY } \\
\text { VARS }\end{array}$
\end{tabular}

$n$ is the degrees of freedom parameter in the Student $t$ distribution. $\rho$ is the number of convergence iterations. 
TABLE 5b

WEEKLY EXCHANGE RATE GARCH MODELS: CONDITIONAL VARIANCE EQUATIONS SAMPLE: 3/87-12/91, 251 obs (Pobt-Louvre Accord)

\begin{tabular}{|c|c|c|c|c|c|c|}
\hline & \multicolumn{3}{|c|}{$\$ / \mathrm{DM}$} & \multicolumn{3}{|c|}{$\$ / Y E N$} \\
\hline & BASIC & $\begin{array}{l}\text { MAGNI- } \\
\text { TUDES }\end{array}$ & $\begin{array}{c}\text { DUMMY } \\
\text { VARS }\end{array}$ & BASIC & $\begin{array}{l}\text { MAGNI- } \\
\text { TUDES }\end{array}$ & $\begin{array}{c}\text { DUMMY } \\
\text { VARS }\end{array}$ \\
\hline$\omega_{0}$ & $\begin{array}{c}0.486 \\
(0.212)^{+}\end{array}$ & $\begin{array}{c}3.593 \\
(0.599)^{+*}\end{array}$ & $\begin{array}{l}0.290 \\
(0.112)^{4}\end{array}$ & $\begin{array}{c}0.406 \\
(0.226) t\end{array}$ & $\begin{array}{c}0.035 \\
(0.053)\end{array}$ & $\begin{array}{c}0.027 \\
(0.056)\end{array}$ \\
\hline$\alpha_{1}$ & $\begin{array}{c}0.711 \\
(0.126)^{\text {** }}\end{array}$ & $\begin{array}{c}0.730 \\
(0.125)^{+4}\end{array}$ & $\begin{array}{c}0.914 \\
(0.038)^{*+m}\end{array}$ & $\begin{array}{c}0.749 \\
(0.118)^{*}\end{array}$ & $\begin{array}{c}0.886 \\
(0.044)^{*}\end{array}$ & $\begin{array}{c}0.877 \\
(0.051)^{+4}\end{array}$ \\
\hline$a_{3}$ & $\begin{array}{c}0.095 \\
(0.073)\end{array}$ & $\begin{array}{c}0.008 \\
(0.034)\end{array}$ & $\begin{array}{c}0.018 \\
(0.024)\end{array}$ & $\begin{array}{c}0.071 \\
(0.049)\end{array}$ & $\begin{array}{c}0.035 \\
(0.025)\end{array}$ & $\begin{array}{c}0.037 \\
(0.026)\end{array}$ \\
\hline$\psi_{1}$ & & $\begin{array}{c}1.324 \\
(0.501)^{* *}\end{array}$ & $\begin{array}{c}0.583 \\
(0.137)^{4 *}\end{array}$ & & $\begin{array}{c}0.250 \\
(0.194)\end{array}$ & $\begin{array}{c}0.171 \\
(0.197)\end{array}$ \\
\hline$\psi_{2}$ & & NA & NA & & NA & NA \\
\hline$\psi_{3}$ & & $\begin{array}{l}11.606 \\
(4.566)\end{array}$ & $\begin{array}{c}0.752 \\
(0.442) \dagger\end{array}$ & & $\begin{array}{c}0,666 \\
(0.351) \dagger\end{array}$ & $\begin{array}{c}0.142 \\
(0.193)\end{array}$ \\
\hline 4. & & $\begin{array}{l}-0.813 \\
(0.297)^{+4}\end{array}$ & $\begin{array}{l}0.353 \\
(0.170)^{4}\end{array}$ & & $\begin{array}{l}-0.286 \\
(0.161)+\end{array}$ & $\begin{array}{l}-0.26 \mathrm{~B} \\
(0.219)\end{array}$ \\
\hline$\psi_{\mathbf{s}}$ & & $\begin{array}{c}-0.058 \\
(0.322)\end{array}$ & $\begin{array}{l}-0.171 \\
(0.089) !\end{array}$ & & $\begin{array}{c}0.241 \\
(0.141) \dagger\end{array}$ & $\begin{array}{c}0.249 \\
(0.155)\end{array}$ \\
\hline$\sqrt{4}$ & & $\begin{array}{c}0.411 \\
(0.150)^{4}\end{array}$ & $\begin{array}{c}0.051 \\
(0.019)^{4}\end{array}$ & & $\begin{array}{l}0.019 \\
(0.011) \dagger\end{array}$ & $\begin{array}{l}-0.016 \\
(0.015)\end{array}$ \\
\hline $\ln L$ & -234.5 & -208.6 & .215 .3 & -223.1 & -202.1 & -200.6 \\
\hline$\rho$ & 14 & 48 & 64 & 25 & 25 & 28 \\
\hline$Q,(10)$ & 13.991 & $17.221 \dagger$ & 13.774 & 15.152 & 8.605 & 10.722 \\
\hline$Q_{2}(10)$ & 2.086 & 11.668 & 12.621 & 5.948 & 7.884 & 9.036 \\
\hline E\&N & as & $\begin{array}{l}\text { positive } \\
\text { size bias }\end{array}$ & $\begin{array}{l}\text { positive } \\
\text { sizo bias }\end{array}$ & ns & ns & ns \\
\hline
\end{tabular}

Standard errors are in parentheses. $\dagger$ denoles ajgnificance at the $90 \%$ leve]; * denotes significance al the $95 \%$ level; * denotes significance at the $99 \%$ level. In $\mathrm{L}$ is the value of the log likelibood function, $\rho$ is the number of convergence iterations, $Q_{\text {, }}$ is the Box-Pierce Q-statistic for the standardized residuals, end E\&N denotes whether any coefficient from the Engle and Ng (1992) dingnostic regression indicates that the GARCH restrictions are violaled. 
TABLE 6a

DAILY EXCHANGE RATE GARCH MODELS; CONDITIONAL VARIANCE EQUATIONS SAMPLE: $1 / 85-1 / 91,1745$ obs

$$
\begin{aligned}
& v_{1}=\alpha_{0}+\alpha_{1} w_{t-1}+\alpha_{2} \varepsilon_{t-1}^{2}+\phi_{1} H_{t}+\psi_{1}\left|I_{r-1}^{U S}\right|+\psi_{2}\left|I_{t}^{m}\right|+\psi_{3}\left|I_{t-1}^{s}\right| \\
& +\psi_{4}\left|I_{t}^{s+a}\right|+\psi_{5}\left|N_{t-1}\right|+\psi_{6} \Delta i_{t-1}
\end{aligned}
$$

\begin{tabular}{|c|c|c|c|c|c|c|}
\hline & \multicolumn{3}{|c|}{$\$ / D M$} & \multicolumn{3}{|c|}{ SRYEN } \\
\hline & BASIC & $\begin{array}{l}\text { MAGNI- } \\
\text { TUDES }\end{array}$ & $\begin{array}{c}\text { DUMMY } \\
\text { VARS }\end{array}$ & BASIC & $\begin{array}{l}\text { MAGNI- } \\
\text { TUDES }\end{array}$ & $\begin{array}{c}\text { DUMMY } \\
\text { VARS }\end{array}$ \\
\hline$\alpha_{0}$ & $\begin{array}{c}0.031 \\
(0.007)^{* *}\end{array}$ & $\begin{array}{c}0.042 \\
(0.010)^{* *}\end{array}$ & $\begin{array}{c}0.042 \\
(0.011)^{* *}\end{array}$ & $\begin{array}{c}0.024 \\
(0.006)^{* *}\end{array}$ & $\begin{array}{l}0.024 \\
(0.007)^{+*}\end{array}$ & $\begin{array}{l}0.025 \\
(0.008)^{4 *}\end{array}$ \\
\hline$\alpha_{1}$ & $\begin{array}{l}0.835 \\
(0.027)^{* *}\end{array}$ & $\begin{array}{l}0.830 \\
(0.028)^{+4}\end{array}$ & $\begin{array}{l}0.828 \\
(0.028)^{* *}\end{array}$ & $\begin{array}{l}0.819 \\
(0.027)^{4 *}\end{array}$ & $\begin{array}{c}0.802 \\
(0.031)^{+4}\end{array}$ & $\begin{array}{l}0.793 \\
(0.032)^{ \pm *}\end{array}$ \\
\hline $\mathbf{\alpha}_{2}$ & $\begin{array}{c}0.102 \\
(0.021)^{+*}\end{array}$ & $\begin{array}{l}0.099 \\
(0.021)^{* *}\end{array}$ & $\begin{array}{c}0.102 \\
(0.021)^{* * *}\end{array}$ & $\begin{array}{c}0.127 \\
(0.024)^{* *}\end{array}$ & $\begin{array}{c}0.124 \\
(0.025)^{* 4}\end{array}$ & $\begin{array}{l}0.133 \\
(0.026)^{* *}\end{array}$ \\
\hline$\phi_{1}$ & $\begin{array}{c}0.166 \\
(0.069)^{*}\end{array}$ & $\begin{array}{c}0.191 \\
(0.069)^{4+}\end{array}$ & $\begin{array}{c}0.191 \\
(0.068)^{* *}\end{array}$ & $\begin{array}{c}0.153 \\
(0.059)^{+*}\end{array}$ & $\begin{array}{l}0.154 \\
(0.058)^{* *}\end{array}$ & $\begin{array}{c}0.152 \\
(0.060)^{*}\end{array}$ \\
\hline$\psi_{1}$ & & $\begin{array}{l}-0.174 \\
(0.101) t\end{array}$ & $\begin{array}{c}0.008 \\
(0.021)\end{array}$ & & $\begin{array}{l}-0.136 \\
(0.066)^{*}\end{array}$ & $\begin{array}{r}0.0008 \\
(0.026)\end{array}$ \\
\hline$\psi_{2}$ & & NA & NA & & NA & NA \\
\hline$\psi_{3}$ & & $\begin{array}{c}0.111 \\
(0.064) \dagger\end{array}$ & $\begin{array}{c}0.009 \\
(0.031)\end{array}$ & & $\begin{array}{c}0.283 \\
(0.168) \dagger\end{array}$ & $\begin{array}{c}0.036 \\
(0.039)\end{array}$ \\
\hline 4 & & $\begin{array}{l}-0.002 \\
(0.034)\end{array}$ & $\begin{array}{c}0.013 \\
(0.035)\end{array}$ & & $\begin{array}{c}0.052 \\
(0.038)\end{array}$ & $\begin{array}{c}0.072 \\
(0.042) \uparrow\end{array}$ \\
\hline$\psi$ & & $\begin{array}{l}-0.019 \\
(0.023)\end{array}$ & $\begin{array}{l}-0.015 \\
(0.022)\end{array}$ & & $\begin{array}{c}0.001 \\
(0.021)\end{array}$ & $\begin{array}{c}0.005 \\
(0.022)\end{array}$ \\
\hline$\psi_{s}$ & & $\begin{array}{c}0.004 \\
(0.002)^{*}\end{array}$ & $\begin{array}{c}0.004 \\
(0.002)^{*}\end{array}$ & & $\begin{array}{r}0.0002 \\
(0.001)\end{array}$ & $\begin{array}{c}0.001 \\
(0.001)\end{array}$ \\
\hline$n$ & $\begin{array}{c}8.441 \\
(1.561)^{4 *}\end{array}$ & $\begin{array}{l}7.838 \\
(1.324)^{* *}\end{array}$ & $\begin{array}{l}8.029 \\
(1.435)^{* *}\end{array}$ & $\begin{array}{l}5.142 \\
(0.667)^{k *}\end{array}$ & $\begin{array}{l}5.327 \\
(0.689)^{44}\end{array}$ & $\begin{array}{c}5.242 \\
(0.669)^{* *}\end{array}$ \\
\hline $\ln \mathrm{L}$ & -939.5 & -923.6 & -921.4 & -676.3 & -651.3 & -652.3 \\
\hline$\rho$ & 11 & 21 & 18 & 10 & 14 & 14 \\
\hline$Q_{f}(35)$ & 35.651 & 34.187 & 33.610 & $46.892 \dagger$ & 38.215 & 40.624 \\
\hline$Q_{r}(95)$ & 46.456 & $63.301^{* *}$ & $53,146^{+*}$ & 26.104 & 22.734 & 22.016 \\
\hline
\end{tabular}

$H$ is the degrees of freedom parameter in the Student $f$ distribution. $p$ jo the number of convergence ilerations. 
TABLE 6h

WEEKLY EXCHANGE RATE GARCH MODELS: CONDITIONAL VARIANCE EQUATIONS

SAMPLE: 1/85-12/91, 362 obs

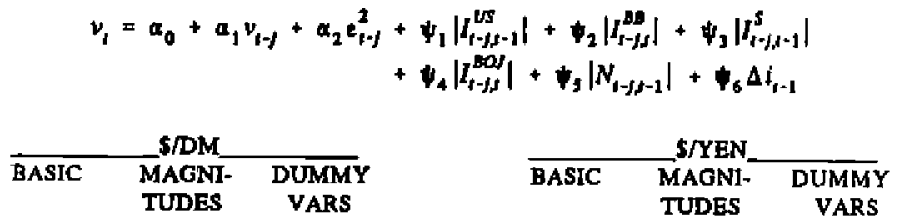

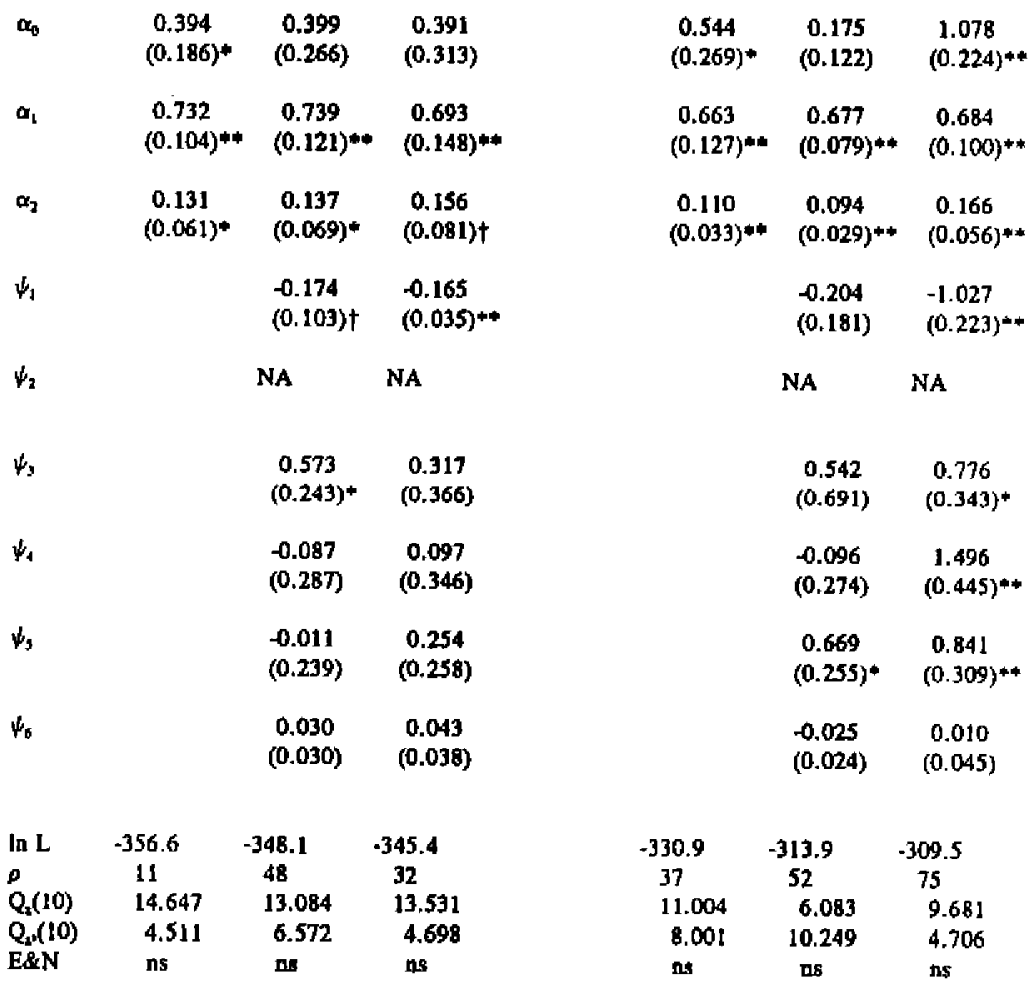

Standard errors are in parentheses. † denotes significunce at the 905 level; * denotes significance at the $95 \%$ level; * denotes significance ot the $99 \%$ level. $\ln L$ is the value of the log likelihond function, $p$ is the number of convergence iterations, $Q$ is the Box-Pieree $Q$-atstiatic for the stuadardized residuals, and E\&N denotes whether any coefficient from the Englo and $\mathrm{Ng}$ (1992) diegnostic regression indicates thet the GARCH restrictions are violaled. 
TABLE 7a

DALIY GRANGER-CAUSALTTY TESTS

DOES VOLATILITY CAUSE INTERVENTION OR DOES INTER VENTION CAUSE VOLATILITY?

$$
\left|x_{1}\right|=\beta_{0}+\sum_{j=1}^{s} \beta_{11}\left|x_{t-1}\right|+\sum_{j=1}^{s} \beta_{2 i} v_{t-1}+e_{1} \quad H_{0}: \sum_{i=1}^{s} \beta_{2}=0
$$

\begin{tabular}{|c|c|c|c|c|c|c|c|c|}
\hline \multirow[b]{3}{*}{$\begin{array}{l}\text { Explangiory } \\
\text { variable }\end{array}$} & \multicolumn{7}{|c|}{ F-STATISTICS } & \\
\hline & & \multicolumn{2}{|c|}{$\$ / \mathrm{DM}$} & \multirow[b]{2}{*}{ (4) } & \multirow[b]{2}{*}{ (1) } & \multicolumn{2}{|c|}{ s/Yen } & \\
\hline & (1) & (2) & (3) & & & (2) & (3) & (4) \\
\hline $\begin{array}{l}\text { reported } \\
\text { Fed } \\
\text { (magnitude) }\end{array}$ & 0.972 & 0.761 & 1.378 & 0.634 & 1.081 & 0.983 & 0.822 & 0.386 \\
\hline $\begin{array}{l}\text { reporled } \\
\text { Fed }(0,1)\end{array}$ & 1.661 & 0.978 & 0.617 & 0.824 & 1.213 & 1.117 & 0.621 & 1.674 \\
\hline $\begin{array}{l}\text { reported } \\
\text { Bundesbank } \\
\text { (magnitude) }\end{array}$ & 1.858 & 1.198 & NA & NA & 0.185 & 0.199 & NA & NA \\
\hline $\begin{array}{l}\text { reported } \\
\text { Bundesbank } \\
(0,1)\end{array}$ & 1.998 & 0.621 & NA & NA & 1.630 & 0.542 & NA & NA \\
\hline $\begin{array}{l}\text { secret } \\
\text { intervention } \\
\text { (magnitude) }\end{array}$ & 1.376 & 0.500 & 1.708 & 1.059 & 0.071 & 0.349 & $3.920 * *$ & I.996 \\
\hline $\begin{array}{l}\text { secrel } \\
\text { intervention } \\
(0,1)\end{array}$ & 1.829 & 0.670 & 0.524 & 0.561 & 0.278 & 0.723 & 0.834 & 1.025 \\
\hline $\begin{array}{l}\text { reported } \\
\text { BOJ }(0,1)\end{array}$ & 1.436 & 0.253 & 0.922 & 0,537 & 1.471 & 2.016 & 0.498 & 1.376 \\
\hline News & 0.676 & 1.443 & 0.646 & 0.749 & 0.739 & 1.753 & 1.389 & 0.806 \\
\hline $\begin{array}{l}\text { Interest } \\
\text { Rale Spread }\end{array}$ & 1.142 & 1.081 & $4.662^{* 4}$ & 1.704 & 0.217 & 0,489 & 1.390 & 0.764 \\
\hline
\end{tabular}

The F-statistics pertain to the hypothesis that all lage of $v$ ire equal to zero; ** denotes significance at the $99 \%$ level. Sample (1) is 1/85-2/87 (Pre-Louvre Accord); sample (2) is 1/85-12/88 (the full sample over which Fed and Bundesbank data are available); samplo (3) is 3/87-12/91 (Post-Louve Accord); Enmple (4) is 1/85-12/91. 


\section{TABLE $7 \mathrm{~b}$}

WEEKLY GRANGER-CAUSALITY TESTS

DOES VOLATILITY CAUSE INTERVENTION OR DOES INTERVENTION CAUSE VOLATILITY?

$$
\left|x_{1}\right|=\beta_{0}+\sum_{i=1}^{3} \beta_{11}\left|x_{r-1}\right|+\sum_{i=1}^{3} \beta_{21} v_{t-1}+\varepsilon_{t} \quad H_{0}: \sum_{i=1}^{3} \beta_{2 i}=0
$$

F-STATISTICS

\begin{tabular}{|c|c|c|c|c|c|c|c|c|}
\hline \multirow[b]{2}{*}{$\begin{array}{l}\text { Explanatory } \\
\text { variable }\end{array}$} & \multicolumn{4}{|c|}{$\$ / \mathrm{DM}$} & \multicolumn{4}{|c|}{$\$ / Y e 0_{1}$} \\
\hline & (1) & (2) & (3) & (4) & (1) & $\overline{(2)}$ & (3) & (4) \\
\hline $\begin{array}{l}\text { teported } \\
\text { Fed } \\
\text { (magnitude) }\end{array}$ & 1.098 & 1.957 & 1.313 & 0.590 & 1.711 & 1.747 & 0.843 & $1.87 T$ \\
\hline $\begin{array}{l}\text { reported } \\
\text { Fed }(0,1)\end{array}$ & 1.053 & 1.087 & 1.662 & 1.363 & 1.313 & 1.717 & 1.620 & 1.919 \\
\hline $\begin{array}{l}\text { reported } \\
\text { Bundesbank } \\
\text { (mngnitude) }\end{array}$ & 0.814 & 1.647 & NA & NA & 0.376 & 1.184 & NA & NA \\
\hline $\begin{array}{l}\text { reporred } \\
\text { Bundesbank } \\
(0,1)\end{array}$ & 1.303 & 1.856 & NA & NA & 1.010 & 1.717 & NA & NA \\
\hline $\begin{array}{l}\text { secret } \\
\text { intervention } \\
\text { (magnitude) }\end{array}$ & 0.454 & 0.682 & $2.479+$ & 0.373 & 0.506 & 0.477 & $2.514^{*}$ & $1.55 \mathrm{~J}$ \\
\hline $\begin{array}{l}\text { secret } \\
\text { intervention } \\
(0,1)\end{array}$ & 1.361 & 0.895 & 0.355 & 0.388 & 0.750 & 0.741 & 1.407 & 0.735 \\
\hline $\begin{array}{l}\text { reported } \\
\text { BOt }(0,1)\end{array}$ & [. 182 & 1.729 & 1.287 & 0.389 & 1.910 & 0.758 & 1.773 & 1.136 \\
\hline News & 0.376 & 1.127 & 2.069 & 0.651 & 0.881 & 0.693 & 1.163 & 1.834 \\
\hline $\begin{array}{l}\text { Inleresl } \\
\text { Rale Spread }\end{array}$ & 1.045 & 0.669 & 1.953 & 0.685 & 1.686 & 0.573 & 1.265 & 0.988 \\
\hline
\end{tabular}

The F-statistics pertain to the hypothesis that all lags of $v$ are equal to zero; * denotea significance at the $95 \%$ level. Sample (1) is 1/85-2/87 (Pre-Louvro Aceord); semple (2) is 1/85-12/88 (the full sample over which Fed and Bundesbank dala are available); sample (3) is 3/87-12/91 (Posl-Louvre Accord); sample (4) is 1/85-12/91. 


\section{References}

Adams, Donald and Dale Henderson, 1983, "Definition and measurement of exchange market intervention, "Staff Studies 126, Board of Governors of the Federal Reserve System, Washington, D.C.

Baillie, Richard T. and Owen F. Humpage, 1992, "Post-Louvre Intervention: Did Target Zones Stabilize the Dollar?," Federal Reserve Bank of Cleveland Working Paper \#9203.

Baillie, Richard T. and Tim Bollerslev, 1989, "The Message in Daily Exchange Rates: A Conditional-Variance Tale," \ournal of Business and Economic Statistics, July, Vol. 7, No. 3, 297-305.

Berndt, Ernst, Bronwyn Hall, Robert Hall and Jerry Hausman, 1974, "Estimation and Inference in Nonlinear Structural Models," Annals of Economic and Social Measurement, 4, 653-665.

Black, Stanley W., 1992, "The Relationship of the Exchange Risk Premium to Net Foreign Assets and Central Bank Intervention ", unpublished, University of North Carolina at Chapel Hill.

Bollerslev, Tim, 1986, "Generalized Autoregressive Conditional Heteroscedasticity," Joumal of Econometrics, 31, 307-327.

Branson, William, and Dale Henderson, 1985, "The Specification and Influence of Asset Markets, " in Handbook of International Economics, vol.2, Ronald Jones and Peter Kenen, eds., North Holland: Amsterdam.

Catte, P., G. Galli, and S. Rebecchini, 1992, "Concerted Interventions and the Dollar: An Analysis of Daily Data," Ossola Memorial Conference, Banca d'Italia, Perugia, Italy, July 9-10; forthcoming in a volume edited by F. Papadia and F. Saccomani.

Diebold, Francis and Marc Nerlove, 1989, "The Dynamics of Exchange Rate Volatility: A Multivariate Latent Factor Arch Model," Joumal of Applied Econometrics, vol. 4, 1-21.

Dominguez, Kathryn, 1990a, "Market Responses to Coordinated Central Bank Intervention," Carnegie-Rochester Series on Public Policy, vol. 32. 
Dominguez, Kathryn, 1990b, "Have Recent Central Bank Foreign Exchange Intervention Operations Influenced the Yen?," unpublished paper, Harvard University, October.

Dominguez, Kathryn, 1992, "The Informational Role of Official Foreign Exchange Intervention Operations: The Signalling Hypothesis, " Chapter 2 in Exchange Rate Efficiency and the Behavior of Intemational Asset Markets, Garland Publishing Company, N.Y.

Dominguez, Katbryn, and Jeffrey Frankel, 1993a, "Does Foreign Exchange Intervention Matter ? The Portfolio Effect," American Economic Review, December.

Dominguez, Kathryn, and Jeffrey Frankel, 1993b, "Foreign Exchange Intervention: An Empirical Assessment", in Jeffrey A. Frankel, ed., On Exchange Rates, Chapter 16, Cambridge: MIT Press.

Dominguez, Kathryn, and Jeffrey Frankel, 1993c, Does Foreign Exchange Intervention Work?, Institute for International Economics, Washington, D.C.

Edison, Hali, 1993, "The Effectiveness of Central Bank Intervention: A Survey of the Post-1982 Literature," Federal Reserve Board, June 12, 1992; forthcoming, Essays in Intemational Finance, Princeton University.

Engle, Robert, 1982, "Autoregressive Conditional Heteroskedasticity with Estimates of the Variance of United Kingdom Inflation, " Econometrica, 50, 987-1007.

Engle, Robert, 1990, "Discussion: Stock Volatility and the Crash of 87," Review of Financial Studies, v.3, no.1, 103-106.

Engle, Robert, and Victor $\mathrm{Ng}, 1992$, "Measuring and Testing the Impact of News on Volatility, "UCSD Discussion Paper 91-12, (revised draft, June).

Geweke, J., Meese, R., and W. Dent, 1982, "Comparing Alternative Tests of Causality in Temporal Systems," Joumal of Econometrics, 21, 161-194.

Ghosh, Atish, R., 1992, "Is it Signalling? Exchange Intervention and the Dotlar-Deutshemark Rate," Journal of International Economics, 32, 201-220.

Granger, Clive, 1969, "Investigating Causal Relations by Econometric Models and Cross-Spectral Models," Econometrica, 37, 424-438. 
Hasza, D.P. and W.A. Fuller, 1979, "Estimation for Autoregressive Processes with Unit Roots," Annals of Statistics, 7, 1106-1120.

Henderson, Dale, 1984, "Exchange Market Intervention Operations: Their Role in Financial Policy and Their Effects," in Exchange Rate Theory and Practice, J.Bilson and R.Marston, eds., Chicago: University of Chicago Press.

Henderson, Dale, and Stephanie Sampson, 1983, "Intervention in Foreign Exchange Markets: A Summary of Ten Staff Studies," Eederal Reserve Bulletin 69, Nov., 830-36

Hsieh, David A., 1988, "The Statistical Properties of Daily Foreign Exchange Rates: 1974-1983," Joumal of International Economics, 24, 129-145.

Hsieh, David A., 1989, "Modeling Heteroscedasticity in Daily ForeignExchange Rates," Joumal of Business and Economic Statistics, July, Vol. 7, No. 3, 307-317.

Humpage, Owen, 1989, "On the Effectiveness of Exchange-Market Intervention," unpublished paper, Federal Reserve Bank of Cleveland, June.

Jurgenson, P., 1983, Report of the working group on exchange market intervention. G-7 Report.

Kaminsky, Graciela, and Karen Lewis, 1993, "Does Foreign Exchange Intervention Signal Future Monetary Policy?," NBER Working Paper No. 4298.

Klein, Michael and Karen Lewis, 1991, "Leaming about Intervention Target Zones," NBER working paper No. 3674.

Lastrapes, William D., 1989, "Exchange Rate Volatility and U.S. Monetary Policy: An ARCH Application," Joumal of Money Credit and Banking, vol. 21, No. 1, 66-77.

Levich, Richard, 1985, "Empirical Studies of Exchange Rates: Price Behavior, Rate Determination and Market Efficiency," in Handbook of International Economics, vol.2, Ronald Jones and Peter Kenen, eds., North Holland: Amsterdam.

Loopesko, Bonnie, 1984, "Relationships Among Exchange Rates, Intervention, and Interest Rates: An Empirical Investigation," Joumal of International Money and Finance 3, 257-277. 
Meese, Richard and Ken Rogoff, 1983, "Empirical Exchange Rate Models of the Seventies: Do They Fit Out of Sample?," Joumal of International Economics, 14, 3-24.

Mussa, Michael, 1981, The Role of Official Intervention. Group of Thirty Occasional Papers, No. 6. New York: Group of Thirty.

Nelson, Daniel, 1991, "Conditional Heteroskedasticity in Asset Retums: A New Approach," Econometrica, 59, 2, 347-370.

Neumann, Manfred, 1984, "Intervention in the Mark/Dollar Market: the Authorities' Reaction Function, "Journal of International Money and Finance, 3, 223-239.

Neumann, Manfred and Jurgen von Hagen, 1991, "Monetary Policy in Germany," in the Handbook on Monetary Policy, edited by Michele Fratianni and Dominik Salvatore, Greenwood Press.

Obstfeld, Maurice, 1990, "The Effectiveness of Foreign-Exchange Intervention: Recent Experience: 1985-1988" in International Policy Coordination and Exchange Rate Fluctuations, edited by Branson, Frenkel, and Goldstein, NBER Conference Volume, University of Chicago Press, Chicago.

Sims, Christopher, 1972, "Money, Income and Causality," American Economic Review, 62, 540-552.

Westerfield, Janice, 1977, "An examination of Foreign Exchange Risk Under Fixed and Floating Rate Regimes," Joumal of International Economics, 7, 181-200. 